\title{
Intelligent Urban Planning and Ecological Urbanscape-Solutions for Sustainable Urban Development. Case Study of Wolfsburg
}

\author{
Joanna Dudek-Klimiuk ${ }^{1, *}$ (1) and Barbara Warzecha ${ }^{2}$ \\ 1 Department of Landscape Architecture, Institute of Environmental Engineering, \\ Warsaw University of Life Sciences-SGGW, ul. Nowoursynowska, 159, 02-766 Warsaw, Poland \\ 2 Independent Researcher, 00-201 Warsaw, Poland; barbara.maria.warzecha@gmail.com \\ * Correspondence: joanna_dudek_klimiuk@sggw.edu.pl
}

Citation: Dudek-Klimiuk, J.; Warzecha, B. Intelligent Urban Planning and Ecological UrbanscapeSolutions for Sustainable Urban Development. Case Study of Wolfsburg. Sustainability 2021, 13, 4903. https://doi.org/10.3390/ su13094903

Academic Editor: Jacques Teller

Received: 7 March 2021

Accepted: 23 April 2021

Published: 27 April 2021

Publisher's Note: MDPI stays neutral with regard to jurisdictional claims in published maps and institutional affiliations.

Copyright: (C) 2021 by the authors. Licensee MDPI, Basel, Switzerland. This article is an open access article distributed under the terms and conditions of the Creative Commons Attribution (CC BY) license (https:// creativecommons.org/licenses/by/ $4.0 /)$.

\begin{abstract}
Intelligent urban planning and ecological urbanism can be recognized as two of the key solutions to act against urban sprawl. This process is associated with suburbanization, blurring boundaries between the city and suburbs, and the undefined role of open and green spaces within new structures. It has been identified as the biggest and the most common problem worldwide. This non-central planning has a huge impact not only on economic aspects, but-most of all—on the ecological and landscaping balance within the urban area. This study covers not only the recognition of the outlined situation, but also a conceptual proposal to challenge the problems of urban sprawl. The city of Wolfsburg serves as a case study to which the tools of Ecological Urbanism and Intelligent Urbanism were applied. A corrective plan for the study area has been worked out, based on the main approaches in urban planning of the 21st century. The green transformation processes to achieve resiliency within urban areas are inevitable and will have to be conducted due to the rising number of the dwellers, steadily changing climate, and socio-economic conditions all over the world. The main solutions include mainly the system of green corridors, interconnectedness of open spaces, walkability with smart mobile options and social community as a nucleus of a local neighborhood.
\end{abstract}

Keywords: ecological urbanism; ecological urbanscape; green infrastructure; urban sprawl; Intelligent Urbanism; urban design

\section{Introduction}

The study focuses on a treatment proposal to create resilient urban areas influenced by the process of city sprawl. Core features of the sprawl are associated with suburbanization, blurring boundaries between the city and suburbs and the function of open and green spaces. It is understood as an unplanned, scattered, low density, automobile-dependent development at the urban periphery. It is caused by non-central planning and highly fragmented land-use governance. These actions result in a single land use, which is dominated and strengthened by car-oriented transportation. This common problem has a huge impact on the economic, ecological, and landscaping balance. Within the whole city-suburb complex, the sense of genius loci, and the esthetic and visual perception may be, therefore, significantly disrupted. To counteract the dispersed forms of the urban structure a holistic strategy is needed to be implemented so as to create a compact and resilient city.

This idea of sustainable growth dates back to the turn of the 19th and 20th centuries when it was an impulse for the creation of many corrective actions for constantly deteriorating living conditions of city dwellers [1,2]. Among them, the most important were the following: a Garden City [1,3,4], a Neighborhood Unit [5-7], and an Organic city [6]. Those three main planning strategies, even if aimed at repairing the living conditions, contributed to the spread of the cities. As a result, in the second half of the 20th century, environmental and climate issues became leading challenges for architects, landscape architects and planners, who looked for solutions to counteract these adverse changes and protect cities 
against threats. The search for corrective approaches for cities is not only based on the economic dimension [1]; it is necessary to respect the laws of nature, prevent, or minimize the negative impact of urbanization and build an intelligent, smart city characterized by sustainable development. Many strategic proposals have been worked out, the most important were Ecological and Intelligent Urbanism. The implementation of these theoretical assumptions (ideas) verified them, pointing to both their strengths and weaknesses.

The purpose of the research is to work out a corrective model (preconceptual proposal) for an urban structure of a previous car-oriented city of Wolfsburg (case study), located in the center of Germany, in the state of Lower Saxony, by using the tools of Ecological Urbanism and Intelligent Urbanism. A new design concept could be a solution to apply the tools of sustainable development in urban areas in a very early design stage. The implementation of systemic pro-ecological urban guidelines and rules of an Intelligent Urbanism can significantly improve the quality of residents' life, especially in large metropolises. The need to develop a new holistic design could be the biggest challenge to make our cities resilient and healthy. This approach should eventually focus not only on one district or precinct, but - most of all—on the urban area as a whole. The guidelines can serve as a basis for a modern and sustainable city design, starting with the genius loci in a local scale $[1,8]$. They should constitute an overall, comprehensive and holistic approach.

Having formulated the objective of the study which was described above, a number of research questions were defined:

- What is the origin of suburbanization? Which of its elements have influenced the current situation in Wolfsburg? What methods were implemented in order to counteract this process?

- Can the tools of Ecological and Intelligent Urbanism be used in the process of repairing the cities or their structures that are currently showing the features of the dispersed forms? What are the basic goals, values, and principles of Ecological and Intelligent Urban planning used in the process of urban repair?

- How can the needs of local communities be taken into account at the level of a preconceptional process? Can local communities be strengthened through such an urban design?

The answers to these questions have helped to describe the problem of the further coherence and sustainable development according to the Principles of Intelligent Urbanism and Ecological Urbanism, and-finally—-to achieve the intended purpose of this study.

\section{Literature Review}

The era of rapid industrialization and early capitalism had an enormous impact on the transformation of cities in the 19th century [1]. A sudden increase in the urban population (which can be also observed nowadays) and the chaotic urban expansion related to that resulted in severe air pollution and poor sanitary and housing conditions. As a response to this development, countless urban planning proposals emerged to heal the everdeteriorating living conditions in the cities [1,5] (pp. 51-54). Among many utopias, the one proposed by Ebenezer Howard - a Garden City — was based on a particular hierarchy and specific spatial order anchored in a central park or garden as an antithesis to a suburb [5] (pp. 59-62), [6] (pp. 58-60), [9,10]. According to some contemporary smart city researchers, this first smart strategic development appears nowadays to be a long-term vision of the future city rather than a reality [3,11-14]. Perry's Neighborhood Unit, which drew from the idea of a Garden City was organized around an elementary school as a self-sustaining, local-concentrated community [5] (pp. 62-66), [6] (pp. 401-403), [7] (pp. 256-270). This cellular unit developed further the notion of contemporary German cities, "of dividing a city into specialized zones" [7] (p. 263). Perry's new system of segregation of movements with blind access to the building complex (dead end), so called cul-de-sac, has become a prototype for new European housing solutions, for instance, "Organic city" by Hans Bernhard Reichow [5] (p. 65) (see chapter 4.1.). The organic city, with its proximity to nature (private garden, greenbelts, and parks) [6] (pp. 86-96), can be further described as 
an urban organism composed of interdependent neighborhoods-different parts of the city's body, based on balance between built and unbuilt areas.

As a consequence, the deliberating ideas of a garden city and neighborhood units have caused a spatial detachment of whole dwelling systems from the city center, which is described today as "urban sprawl". This tendency dates back to the 1920s [15-17], was described in the 1930s [18] (p. 177), [19] (pp. 52-53), and the 1940s [18] (p. 177), [20] (p. 15) of the last century and was first observed on an enormous scale in the United States after World War II [1,5] (p. 76). Litwinska mentions that there is no single definition of the phenomenon of urban sprawl [15] (p. 146) and there are many, sometimes mutually exclusive, characteristics [21] (p. 108). Consequently, the impulse for the formation process in Great Britain was rail transport [15] (p. 146), whereas in America-the mass produced cars [22], which forced inhabitants to use private vehicles as a means of transportation [5] (p. 65), [6] (pp. 400-404), [15] (pp. 140-141), [21] (pp. 107-118). This heritage of AngloAmerican ideas for the corrective plans of healing for the urban tissues had been mutually influenced by the European ones and further developed. Further in Europe, the new planning systems were adapted. This process transformed planning strategies worldwide. The present times, urban planning as a discipline deals with the construction and expansion of cities, remaining in the mutual correlation with the town's policy, governance, and longdistance planning strategy. However, it is essential that the new approaches do not cause further uncontrolled sprawl of cities. The goal should not be to found the new, ideal colonial cities, but rather to cope with the existing imperfect urban tissues. Ecological concerns and urban objectives should rather complement each other, creating the planning coexistence. It is not the issue of spreading the built-up land into the landscape-on the contrary-the main corrective plan could be based on introducing the ecology standards into the city. According to Martha Schwartz, ecological urbanism, as a comprehensive approach, has the strength to combine these conflictual conditions. She is convinced that there is a great challenge for landscape architects to bring functional and rational planning of open spaces into the city, to include human systems as a part of ecology. This process is and should be taken into consideration to develop a sustainable urbanscape [23] (pp. 524-525); consequently, Ecological Urbanism must be focusing on green [24] and blue infrastructures as planning objectives of modern city planning.

Ecological aspects of urbanism are based nowadays principally on the sustainable development and resiliency of urban tissue. Ecological urbanism or an 'ecological definition of urbanism' focuses on the basic characteristics of urban planning, policies, and logic between the structure and form. It is also a new proposal in the relationship and perception between a man and the environment [17]. The values of ecological urbanism, such as public good and cultural ethics, are universal and differ from one continent to another due to geographical or weather conditions, orientation, or level of pollution. Resiliency to rapidly changing living conditions around the globe and an increasing number of the urban population (according to the UN two-thirds of the world population will live in cities by 2050, [25]) should be the main concern for this movement.

The determining criterion that advocates for the sense of ecological urbanism named by Mostafavi remains the density [23]. It is crucial to set a long-term plan towards compact cities with a close collaboration between public and private sectors. The city governors should take a huge responsibility to set directions for the future urban development. The responsibilities of city governance are, nowadays, far beyond only planning the city's maintenance [23]. Mostafavi stresses the fact that ecological urbanism should be based on such values as biodiversity, but not only on the level of quantity of species. The goal should be rather the 'biologically diverse urban landscapes' as a place for recreation and social interactions. It cannot remain only a basic green infrastructure [24]. The emphasis should also be put on the local production of food, even within the city tissue, strengthened by the cooperation with local farmers and markets [23].

Corrective actions undertaken by the political powers are inevitable to apply the ideas of Ecological Urbanism against uncontrolled suburbanization. Zuziak [17] emphasizes 
that political interaction in the strategy and the democratization of public life support the integration of spatial and strategic planning, which is not always implemented and often remains at the level of pure political ideology. Litwinska [15] (pp. 141-145), on the other hand, lists European metropolises like Bremen in Germany or Brussels in Belgium, whose municipal managers and governors approach strategically and deliberately the issues of the sustainable development of their cities as a whole. To prevent urban sprawl, algorithms and simulations have been prepared. They show the consequences of specific development directions based on the extension of public transportation. This emphasizes how complicated and complex sustainable urban planning is and how many disciplines it takes to organize the urban landscape that is the most beneficial to the health of the city and its inhabitants. This is a good example for modern governance and the importance of rational control of urban sprawl.

Intelligent city development, created in the 21st century [26], promises a much more holistic approach to contemporary urbanism, where digitality and reality come together. Therefore, the identification of an intelligent city is often replaced by a "smart city" or "digital city". Nevertheless, all these definitions have not been characterized consistently $[3,27-30]$. One thing seems to be certain-its goal is to create a coherent, compact, urban entity, unity of all components, an integrated urban ecosystem [3] -an antithesis to the sprawl. This long-term strategic development assumes a permanent improvement of living conditions and reduction of functional costs at the local and regional levels. This concept is aimed at effective management of the city's resources in the process of its development and during its operation. The Principles of Intelligent Urbanism are as follows: a balance with nature, a balance with tradition, conviviality, efficiency, human scale, opportunity matrix, regional integration, balanced movement, institutional integrity, and vision [26,31-33]. They are used to control and act against the urban sprawl and transform the city into a compact one.

Intelligent development integrates diverse urban planning solutions which are based not only on well-defined streets, open spaces, building layout [26,31-33], and cultural amenities [34] but also redefine the intelligent systems and automated means of transport $[35,36]$. In order to regain "the significant relationships between theory and practice, understanding and proposal, and between physical dimensions and economic and social dimensions of change towards intelligent territorial planning", an integrated approach must be adopted [37] (p. 120). The same applies to models of ecological connectivity [37]-a smart environment [38]. Sustainability objectives, which should serve as 'guidelines' for the European cities, can enhance intelligent and sustainable urban development. This development towards a 'green' city with all ecological features and logical connections provides cities with resiliency and tools to 'act against' climate change successfully [37,38]. According to the European Commissioner for the Environment, Kermenu Vella, the " $[\ldots]$ green cities can make more: they offer a better quality of life to their inhabitants and new business opportunities" [37] (p. 119), [39]. The key characteristics include a set of planning strategies based on innovative and optimized use of public services in the crucial areas, mobility, energy, and environmental efficiency. Their goal is to meet the needs of citizens and improve the quality of urban life [3,30,37-43], which "[ ... ] should be expressed by a number of criteria that are individually formulated for each city" [38] (p. 9). It is established on cultural heritage, natural and human resources. Special attention should be, therefore, drawn to the historical-cultural resources of cities, which remain a great existing capital to shape the urban structures anchored around main landmarks. It seems that a spatial development based on such physical values enhances the urban atmosphere and creates an authentic urban lifestyle [43,44]. Consequently, the technology remains only a 'tool' of smart-sustainable development [35,36]; the human interests and activities are foregrounded [30,38,45].

Green infrastructure as a part of intelligent planning in terms of the ecological, environmental, economic, and social benefits, can be achieved through harmony with nature $[24,37,43]$. 'Nature' can be broadly represented by natural or designed green spaces as 
a part of the sustainable development of the urban fabric. Together with the blue infrastructure, it becomes a holistic feature of an ecosystem, able to mitigate the consequences of climate change [37,38]. "The green infrastructures are identified as 'eco-duts', ecological corridors, hedges, rows, green bridges, and all those linear entities that allow to reconnect natural or semi-natural areas (point area entities), which have been artificially fragmented by artifacts, buildings, roads, or railway lines" [37] (p. 123), [46]. The long-term perspective of their development should be regarded in such values as air and water quality, physical activity, aesthetic [38,47], social integration, inclusiveness, and sense of security [48]. Water features like rivers, ponds, wetlands, waterfronts complement green ecosystems, create the hydrographic networks and strengthen green corridors, which help to balance violent consequences of climate change. They also help with water retention and air cooling.

To sum up, the values of Ecological Urbanism are based primarily on sustainable development and biodiversity understood as the presence of a high number of species and a variety of open spaces. A compact city with balanced proportions of the urbanscape elements should be the goal of the public-private partnership. Intelligent Urbanism is based on the considerate approach towards nature, focus on the efficiency of resources and use of the appropriate technology in coping with environmental issues. The idea of implementing the human scale approach in any actions in the local governance helps to achieve regional integrity. The elements of mobility are balanced with the walkability within the pedestrian-friendly street life.

The active participation of residents and businesses together with good governance through the bottom-up approach is necessary to promote new solutions and political decisionmaking [3,37,38,42]; hence, Intelligent City should be a city for all citizens [3,42,48-51]. It should reflect the basic human values and needs as optimal conditions represented on the level of a place, urban space and urbanity. Smart electronic solutions can improve access to public services as well as information and increase the partaking at the level of design and operation of the city; consequently, they should contribute to reduction of social exclusion $[36,48,50]$. Social participation can be thus called "the main factor influencing the outcome of the changes, people must be willing to use and participate in smart solutions" [38] (p. 10) and can be given that chance through the use of electronic means $[36,50]$; therefore, it is next to the environmental and economic concerns one of core elements of sustainable development. It can be even observed that at the interregional level individual cities compete with each other for the title of a smart space of dynamic growth connected to economic city branding [52], and creative and physical capital and its mobility, which appears to be measurable in economic costs-taxes income [45]. However, "place attachment is the ability to use public space [48] (p. 82), [51]; consequently, the core of urban living lies in the human and social capital [29,42,48,51]. Therefore, the solutions of Intelligent Urbanism cannot be implemented only partially-all the objectives are required in all sectors, generations, and domains $[3,48-51,53]$. This is featured by the environmental layer in regard to the blue-green infrastructure and social one-as active local centers of human interactions, facing the cultural challenges of intelligent communities [45,51].

High quality of life remains one of the main ambitions of the European Commission, which is committed to supporting the development of green cities [30,37,54]. The awarded European cities are characterized by intelligent planning strategies adjusted to local conditions and their successful adaptation in order to create an environmentally friendly urban development, which can guarantee economic resiliency and qualitative sustainability. It often seems to be the case that the probability of designing and implementing objectives of Smart City is higher in cities that are already familiar with executing intelligent characteristics and policies $[50,55,56]$. Market pressure and weak governance can contribute to a failure to implement smart theory into practice [56]; hence, the performance of planning objectives can only be possible in the "presence of a strong political-technical leadership and an institutional framework with instruments of government of the territory able to make complex interventions possible" [37] (p. 122), [50,56,57]. 
The implementation of smart growth as a holistic strategy seems to be limited rather for the wealthiest and well-developed countries [55]. Since their impact on the environmental commonwealth has been the strongest-their actions towards sustainable growth are expected to be applied accordingly [3]. Even so, the natural limits of our planet and its natural resources required for such transformation remain the obstacle, which prevents sustainable development from happening. Additionally, there is the question of whose interest is represented here the most: marketing needs of corporates or social intelligence required for cities to be smart. Smart as one city might eventually become, it is essential to concentrate on a community-led transition which achieves resiliency to acute social, economic, and cultural challenges [58].

\section{Materials and Methods}

The Methodology is based on:

- a logical argumentation (literature review, analysis and description of the state of the research),

- $\quad$ interpretive-historical research with the case study of the city of Wolfsburg, Germany

- $\quad$ simulation and modeling research with a conceptual proposal for this case study.

The research was divided into several stages, in which different research methods were used depending on their specificity. In the first stage, the method of logical argumentation was applied and the literature on the subject was reviewed in order to compile basic definitions related to suburbanization and their critical interpretation. On this basis, the historical background and basic conditions of both suburbanization processes and attempts to counteract them (old and modern) were delineated. Materials and publications used at this stage of the research were quoted in the text of the article.

Based on the results (features characterizing the phenomenon of suburbanization), the object of further, deepened research was selected.

The main part of the presented research concerns Wolfsburg, Germany, a city facing strong suburbanization. This part of the research was conducted with the help of a case study method, which was accompanied by an historical-interpretative approach. The tools used in this part were as follows: literature research, analysis of logical argumentation, correlation of events, and facts. This part was mainly based on publications, including exhibition materials on the history of the city and archives kept at the city hall. The assessment of the land development condition and its use was based on the analysis of planning materials (Spatial Development Plan, digital ALKIS Stadtgrundkarte (2018)) as well as on the analyses of orthophotos and environmental diagnosis maps (noise, flood risk). On top of that, field observations constituted a vital portion of this evaluation. The demographic data was obtained from a socio-political analysis (2018) and publicly available statistical data.

The city of Wolfsburg was selected as the study area due to its size and the current state of the problematic urban structure. It seems to be an adequate object for further studies and considerations. The openness of the City Hall and the willingness of its administrators to cooperate had a significant impact on this study.

Thanks to the data collected, it was possible to describe the development of the city, its history, the correlation between historical and social facts as well as the city's spatial development. A diagnosis of the condition was developed and potential directions of corrective actions were indicated. The intended target, which-in this case-was developed in the form of a project-a corrective model, utilizes the tools of Ecological Urbanism (simulation and model studies).

The solution which was developed proves that it is possible not only to prevent further suburbanization but also to repair structures (cities) already affected by this problem.

\section{Conceptual Proposal}

The presented planning proposal for the city of Wolfsburg was taken from an earlier thesis entitled "Coherent city of Wolfsburg" by Warzecha, B. [59]. It aims to present the 
objectives of Intelligent Urbanism and Ecological Urbanism and is an important element of problem-solving possibilities presented in the article. The study area (in situ research) is situated in the northern part of the city in the vicinity of the Old Wolfsburg and Volkswagen factory (Figure 1). The project of coherent Wolfsburg described below as a case study has been entered for the student ideas competition of the city of Wolfsburg "WOLFSBURG AWARD for urban vision" in 2020 [60].

A number of project problems related to the case study were formulated:

- What types of intelligent transportation can make neighborhoods resilient? How to act against traffic congestion within the city core? How to create an intelligent and environmentally friendly transport concept?

- Can the quality of life of city dwellers be improved with special regard to open and green spaces? How to create an 'edible city' for humans and city animals?

- Can biodiversity and quality of green areas within the urbanscape and their interconnectedness be improved? What kind of plants are to be used in order to create biodiversity within specific green spaces?

- What should be the functional programme of single green spaces within an urban ecological corridor? How should they interact with the surrounding urban tissue, greenbelts, and landscape?

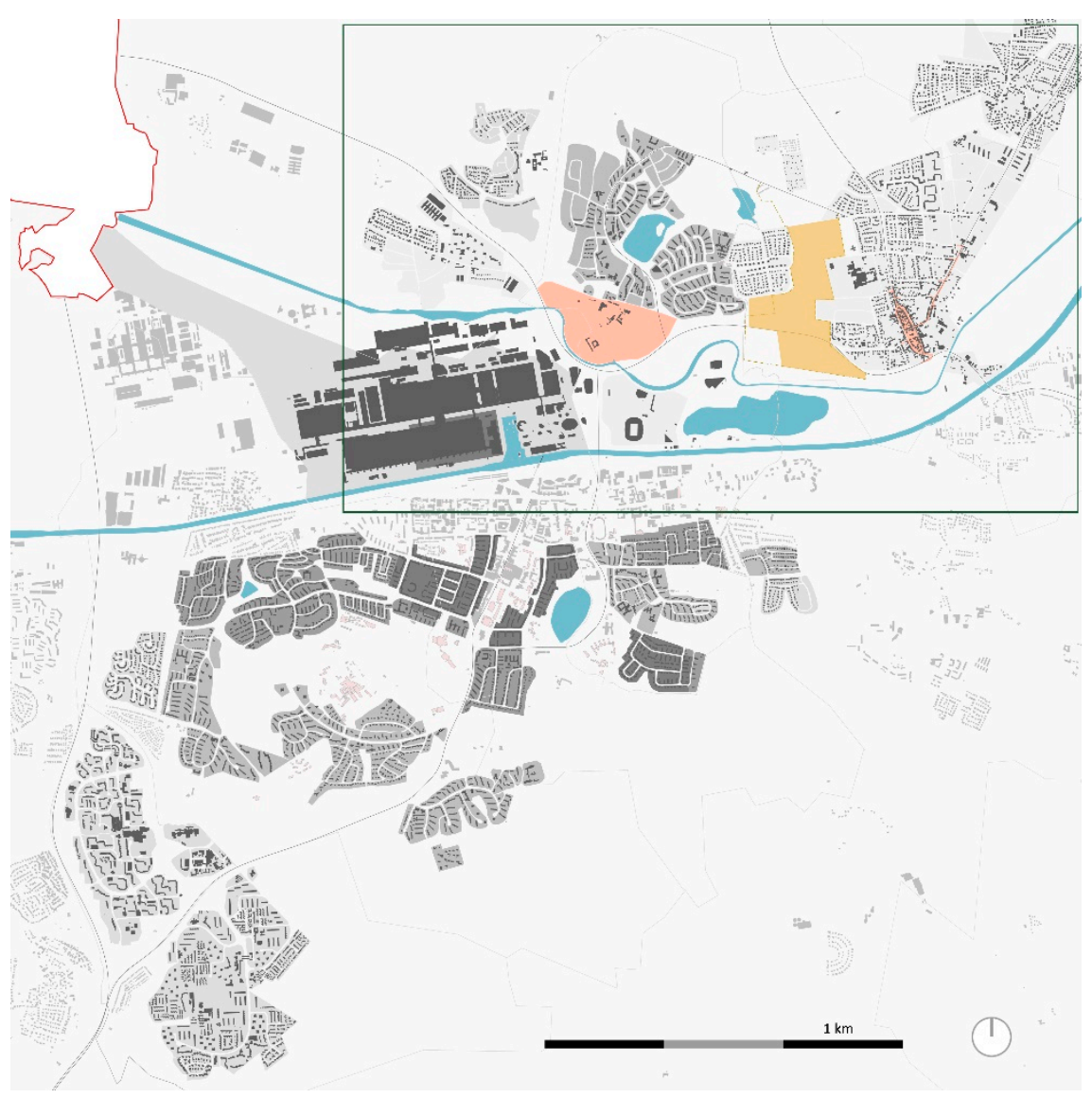

Figure 1. City of Wolfsburg nowadays. Housing estates seem to be scattered and incoherently planned. The VW plant is the most dominant figure of the city. The red area represents the AltWolfsburg and Vorfsfelde, yellow-planning site/study area. Without a scale. Own elaboration based on the digital ALKIS Stadtgrundkarte (2018) of the city of Wolfsburg.

4.1. Historical Background of the Urban Development of Wolfsburg. The Green City of Wolfsburg

Wolfsburg is a city that has struggled with the urban planning and development processes just like any other city. However, what makes it unique (and is rarely the case 
in Germany), is the fact that the cityscape has been shaped by historical conditions and many urban planning models (only) since the 20th century. The most important planning strategies to be mentioned are the following: functional garden city (1938-1944); organic and automobile city (1947-1963); and spatially separated, sprawled city (1961-1998) — the characteristics of which are described above. This has resulted in a development of a patchwork family of the city districts, a specific small-scale structure and an island-like, inconsistent living space [61] (p. 8).

The first settlement of Alt-Wolfsburg was founded in the Renaissance era and was limited to the castle and accompanying buildings, which crowned over the swamp landscape. The first urban development was organized at the newly build Mittellandkanalin the middle of the former German Reich, in the immediate vicinity of the industrial center Braunschweig-Salzgitter-Magdeburg [61] (p. 14). The railway station and the production line for Volkswagen cars with the adjacent factory settlement, were established in May 1938-at Hitler's request. This first spatial concept (Figure 2) [62] was planned by Peter Koller as a model, functional, "industrial city as a garden city" (city center and Steimker Berg district, 1938-1944) [61] (p. 9). It was characterized by a strict distinction between factory (to the north) and city (to the south) [63] (pp. 31-33). The center of the new settlement with the Klievensberg Hill was connected to the Alt-Wolfsburg Castle via the southwest-northeast axis (further described as a "Cultural and Recreational Axis"), on which the new city was spatially organized. Most of the three-storey housing units were arranged in an open and green block perimeter development, with access roads leading into it from all sides. Due to the acute shortage of materials and the lost war, the first project of the city failed and the growing settlement structure took on the name of a nearby castle-Wolfsburg [61] (p. 20).

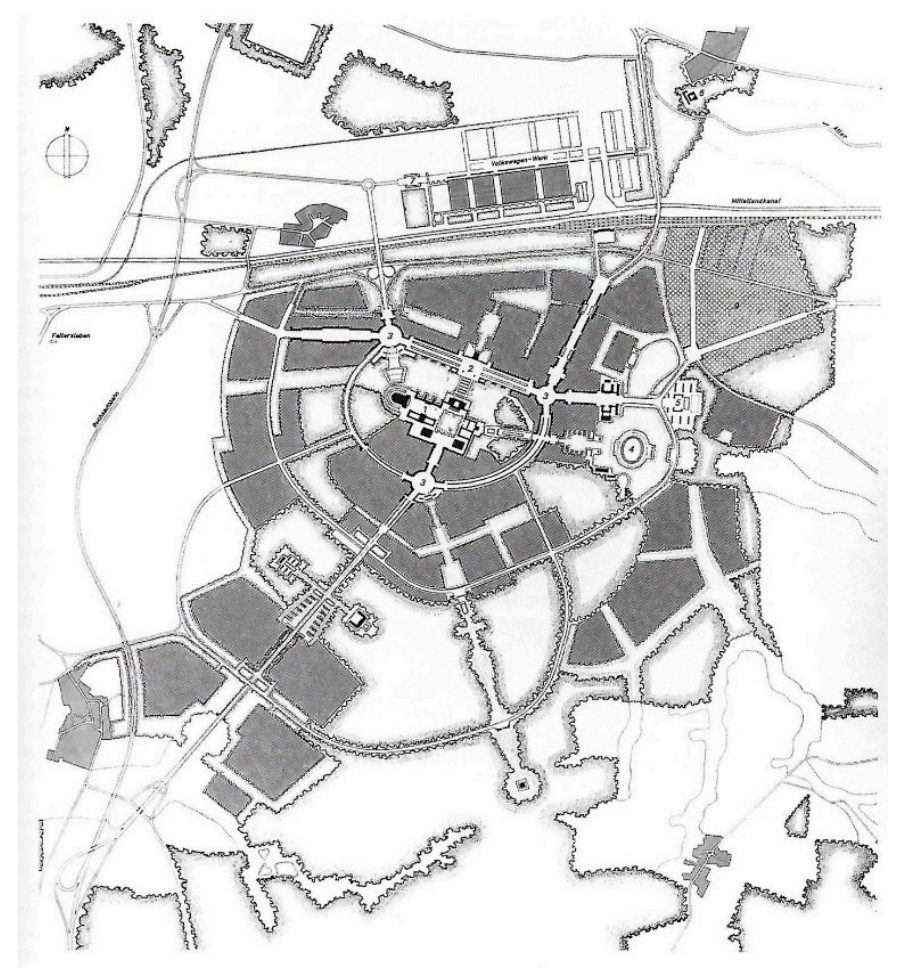

Figure 2. The city of the Volkswagen car, concept plan of an 'industrial city as a garden city' aimed at the north-south direction of the city's development, draft by Peter Koller, 1938, [62] (p. 43).

The economic boom between 1947 and 1963 enabled the city to grow again. The new expansion of a small precinct was planned by Hans Reichow according to a new axis to the west-east direction, which now covered only the southern part of the city. As depicted 
(Figure 3), the already existing Garden City (in the middle with black building figures) was surrounded by new settlements, which seem to be chaotically submerged in greenery; there is no coherence between single housing estates. This new planning strategy of a "scattered and loose city", "organic and automobile city" sprawled into the juxtaposed landscape (e.g., the Rabenberg settlement) and changed the strategy of the future urban development enormously. From now on, the city was divided into functional zones, as new residential areas were planned and built as 'stepping stones' in green areas and only on the southern bank of the Mittellandkanal.

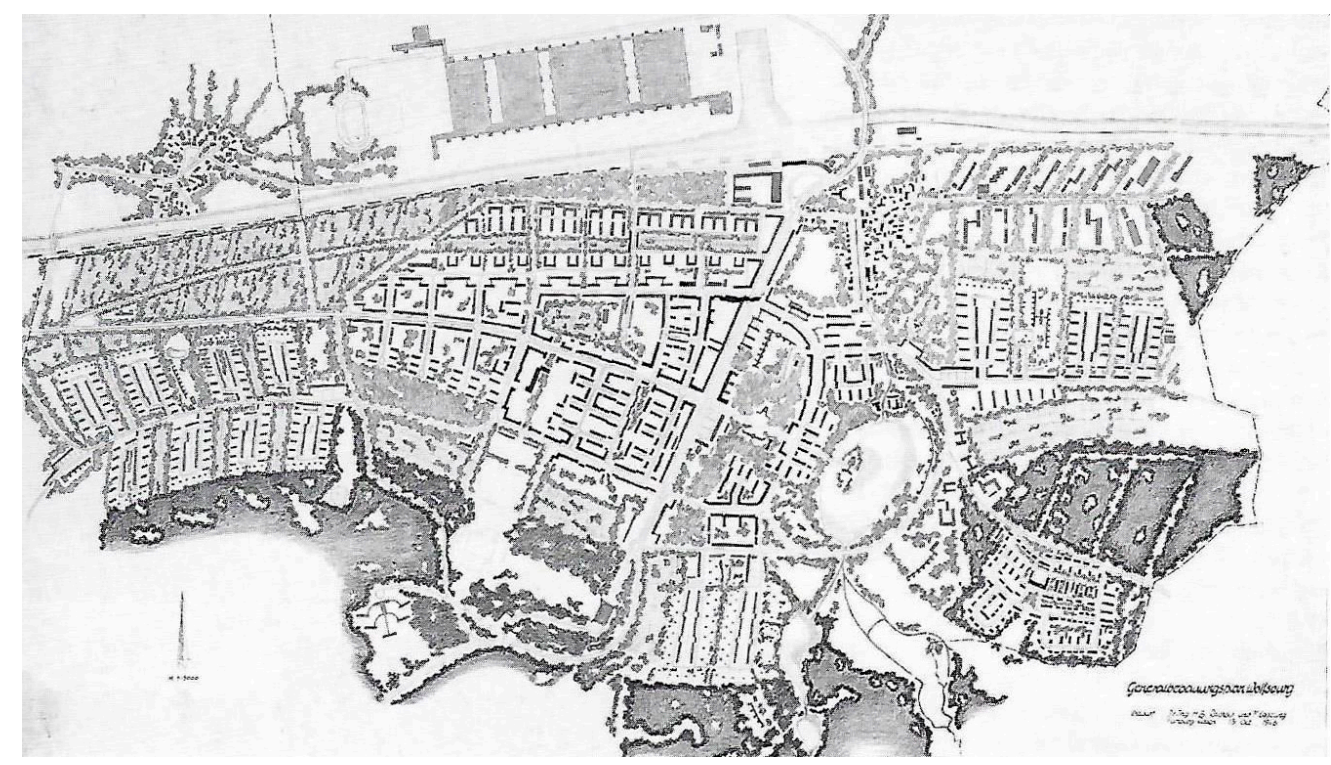

Figure 3. The organic and car-friendly city of Wolfsburg [62] (p. 41).

The most significant development of the city, which triggered the actual beginning of its sprawl character, took place between 1961 and 1998 (see also Figure 1). The further city growth intended to include a variety of building forms and social mix (but not a mixed use). This spatial and architectural experiment was designed as self-concentrated satellites, composed with no surrounding attachment. In this island-like urban structure the individual settlements were integrated into the urban landscape independently of one another over the course of time (eventually also in the northern part of the city). The patchwork-like building tissue seemed to have been created in an unplanned way and competed with the open space structures. The most significant characteristic of that design was the spatial separation of functions between "working", "living", and "leisure". An attempt was made to gradually reflect the proportional relationships between buildings and the green and traffic areas, also between the density and insolation in each district [61]. The northern part of the city, which had not been included in spatial strategies of the city for decades, has recently gained new island-like settlements. They have been organized around the historical parts of the city-the castle of Alt-Wolfsburg and the core of Vorsfelde district (further described as a "Historical Axis"). Due to the fact that this is the youngest and dynamically growing part of the city, it has an enormous potential for changing its sprawling character, starting with the study area and further on spreading on the city as a whole. Therefore, the preconceptual proposal will focus on the creation of a compact built-up area, using the tools of Intelligent and Ecological Urbanism.

Holistically speaking, Wolfsburg is nowadays divided into northern and southern parts by the Mittellandkanal, the railway line and the Aller valley which emphasize its spatial incoherence. Surrounded by a flat landscape with floodplains, filled with forests and farmlands, Wolfsburg offers a unique quality of living and working. The whole city area is as big as 20,452 ha with a huge proportion of the diverse structure of open, recreational and protected spaces (biotopes). Water features amount to over $3 \%$ of city 
land coverage (use); recreational areas-13.6\%; forests-24\%; and agricultural land-41.2\%. All in all, around $60 \%$ of the urban tissue is filled now with open spaces, which makes Wolfsburg the greenest German city [64]. It is important for the residents to continue living in country-like surroundings and to be able to use the existing infrastructure. A strategic development should also address the issue of a growing residential population with a special regard to the balance between the green and built-up areas. It is essential to create such a development, which opens up to green spaces as an additional, functional part of the urban tissue. The tools of Intelligent and Ecological Urbanism can be used here as an overall sustainable strategy.

\subsection{Analysis of the Current Situation}

The edge of city structure (Figure 4) is easy to isolate from vast open spaces within the town's boundaries. The northern part of the city of Wolfsburg houses the Volkswagen plant and recreational areas with the floodplains of the Aller River. It also has a clear island-like structure of the built-up area. The traffic system has its hierarchy and streets are characterized by different widths. Spatially separated, individual settlements are embedded in the open space. They are linked to each other through the district's main streets, which function as traffic collectors within built-up neighborhoods. Organically formed residential streets depict the flow of the traffic system in new districts. The contemporary streets of Vorsfelde follow the old structure of field paths. They are based on a grid plan.

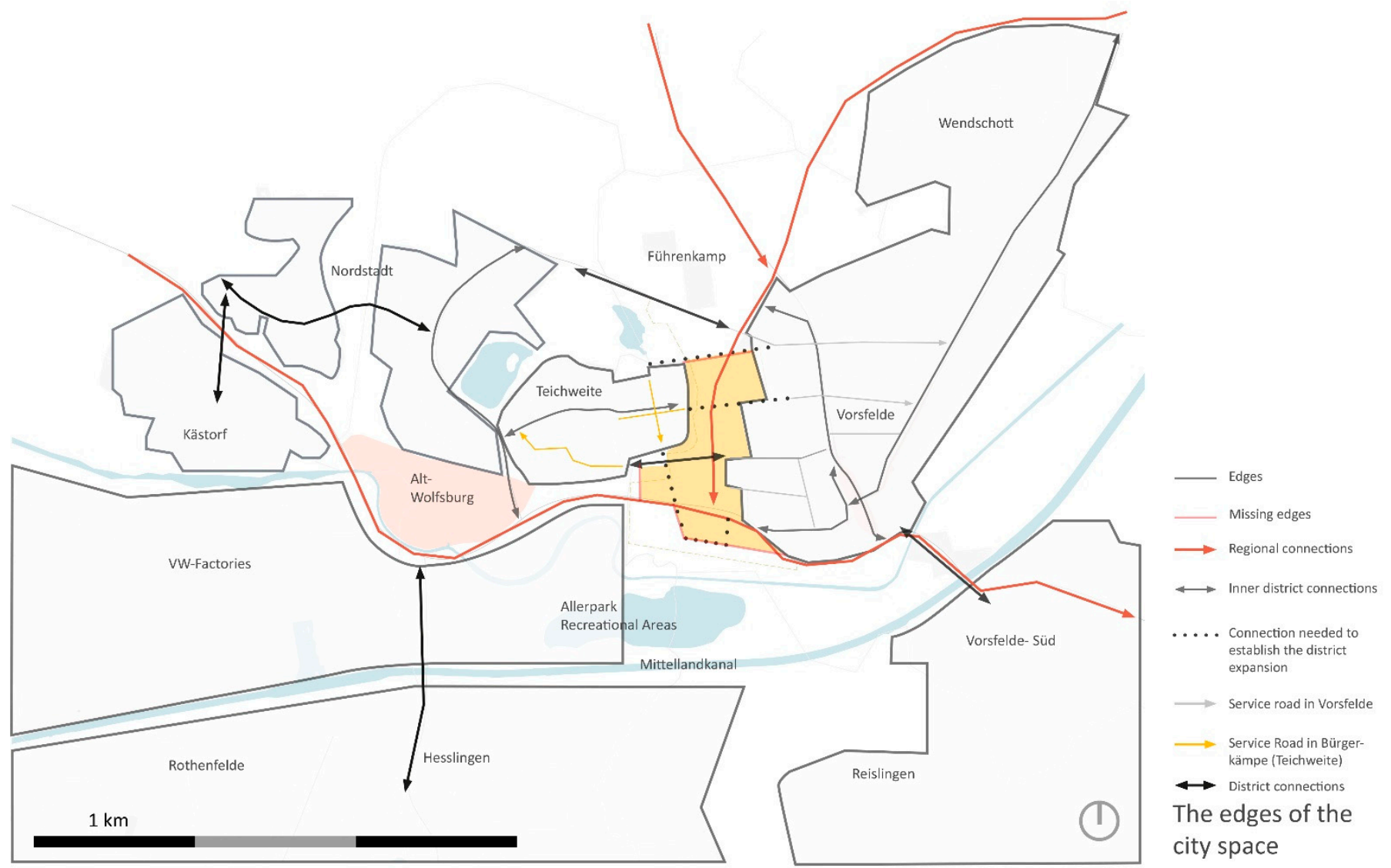

Figure 4. The edges of the city space. The scattered settlements are situated between the intercity roads. Own elaboration based on the digital ALKIS Stadtgrundkarte (2018) of the city of Wolfsburg.

A federal road, which does not impair settlement structures, runs through open spaces between districts in the north-west direction. The country road L188 runs similarly in a north-south direction and joins the federal road at the main junction. 
The connection with the city center from the north is provided by a bridge east of the border of the VW plant. Another bridge connection is situated between Vorsfelde and Vorsfelde Süd and has no direct road connection with the city center. The northern part of the city appears to have neither a central point or street nor a landmark.

The city of Wolfsburg is very conveniently located on the Mittellandkanal, in the eastern part of the state of Lower Saxony, Germany. The highways A2 and A39 and the west-east railway lines run through the town. The A 39 motorway and the north-west federal highway 188 run through the city in a north-south direction. The city center and structures of Alt-Wolfsburg and Vorsfelde lie on the natural course of the Aller River. The train (InterCity Express ICE) connects the city with the capital of Germany in only one hour (up to two trains an hour), the regional train connects the entire region. The neighboring city of Braunschweig is only 20 min away. The city of Gifhorn can be reached by private transport within $30 \mathrm{~min}$ or by regional train in $15 \mathrm{~min}$. Braunschweig-Wolfsburg Airport is located $80 \mathrm{~min}$ away if one travels by public transport or just $25 \mathrm{~min}$ away if one chooses a car.

The city of Wolfsburg is known as a commuter city due to a good network and high staffing requirements of the VW factory (76,771 commuters in 2017). The Volkswagen factory and associated facilities are classified as a special district of the town. The city is made up of a total of 13 districts.

According to Wolfsburg statistics for 2018, around 125,244 people lived in the city in $2017,50.2 \%$ of whom were women. The city had a negative natural balance $(-239)$ and a positive migration balance $(+222)$. Around $61.5 \%$ of the population were in the productive age, in 2025 this will probably be $60.9 \%$. The number of minors was around $16 \%$ in 2017 and will be $17.7 \%$ in 2025; seniors: $22 \%$ and $21.4 \%$ respectively [64].

In order to present the data for the city of Wolfsburg against the background of other cities in the state of Lower Saxony (German: Land Niedersachsen), two cities comparable in terms of total area from the closest region of Wolfsburg were taken into account. It was decided to omit such urban complexes as Bremen with Bremerhaven (a separate state) or Hanover (state capital) due to their administrative status. Hanover, although it has a city area similar to the one of Wolfsburg, has many times more inhabitants $(20,430$ ha, 535,061 inhabitants, 2,144,120 inhabitants in the agglomeration [65]). Even though Hanover and the Bremen complex are industrial centers, they will not be taken into account for the above-mentioned reasons in a further comparison. Another urban complex that will be excluded in this process is the city of Göttingen, which due to its function as a student and tourist city has a different development profile (it is not an industrial city).

In addition to Wolfsburg, the following cities can be, therefore, enumerated in the region: Braunschweig with an area of 19,270 ha with 250,361 inhabitants [66] and Salzgitter with an area of 22,392 ha with 107,014 inhabitants [67] (data as of 31 December 2017). Converting the area of the city to one inhabitant, we get 0.16 ha/inhabitant in Wolfsburg, 0.08 ha/inhabitant in Braunschweig, and 0.21 ha/inhabitant in Salzgitter.

The total number of green areas in Wolfsburg is 60\% [64], in Braunschweig-53.2\% [66], and in Salzgitter-71.5\% [67] respectively. Converting the green area to one inhabitant, we get 0.10 ha/inhabitant in Wolfsburg, 0.08 ha/inhabitant in Braunschweig and 0.15 ha/inhabitant in Salzgitter.

All residents of the city declare their main residence in Wolfsburg, an additional 8901 as a secondary residence. The households consisted of an average of 1.9 people, $47.2 \%$ were only inhabited by one person. In Salzgitter and Braunschweig, this structure is similar.

The unemployment rate was $4.7 \%$ and the city had 3150 unemployed inhabitants registered. 72,844 people were employed in the manufacturing sector at the place of work, 76,771 people commuted to the city. Wolfsburg is a car-oriented city-134,756 cars were registered in 2017, which means that there are around 2 cars per household [64]. To sum up, there are more cars in this city than there are inhabitants.

The original urban axis from 1938 visually connects the Porsche Street (today a pedestrian zone) in the southern part of the city with the castle that crowns the city in the northern 
part. Unfortunately, this infrastructural and spatial linkage was interrupted, when the Autostadt (delivery center for the new cars produced at the VW plant, museum, and an amusement park) was rebuilt in the early 2000s. The pedestrian crossing to recreational areas at Allersee takes place through two existing traffic bridges upon the Mittellandkanal (one at the VW Autostadt, the second one in Vorsfelde) and the pedestrian bridge on the Allersee. An additional car-free connection between the new quarter and the city center as the southern part of the city would improve mobile networking (Figure 5).

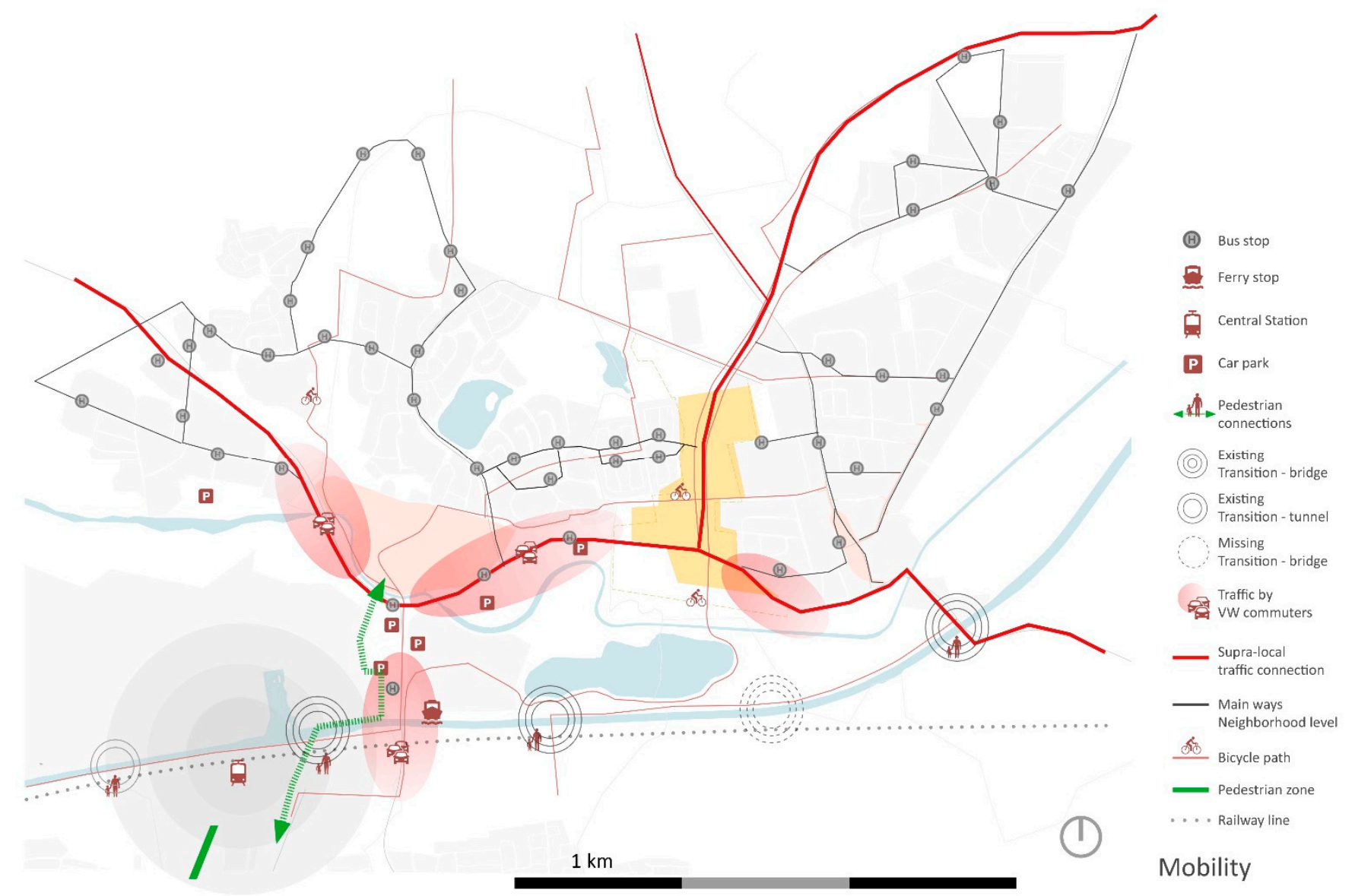

Figure 5. As a typical automobile-dependent city, Wolfsburg is dominated by the vast roads, mostly intercity networks, which are very often jammed by the commuters (red area) from the Volkswagen factory. Own elaboration based on the digital ALKIS Stadtgrundkarte (2018) of the city of Wolfsburg.

The supraregional and local railway station is located directly by the VW plant, the line follows the Mittellandkanal. Moreover, the federal road runs through the northern side of the town in the north-western direction and absorbs a high level of traffic. During shift changes, it is severely affected by traffic jams at main intersections. A bus line with a network of stops runs parallelly on the main streets of the district. The bike and car routes are separated from the pedestrian traffic and embedded in the green spaces, which is typical of an automobile city.

The land use types of the northern part of the city shows a homogeneous structure of the built and unbuilt spaces. It functions mainly as a "bedroom city" with a significant proportion of residential areas. The schooling facilities with sports areas, as well as educational centers that are spread across the residential islands, are intended for the youngest residents. The main landmark in the northern urbanscape is the VW plant-the city's main area of commerce and industry, located in the western part. Other industrial areas are linked to the canal in the south. A belt of forests and dense parks, which seems to share the 
urban tissue with built-up areas, plays an equally important role. A single shopping street is found in the center of Vorsfelde (Figure 6).

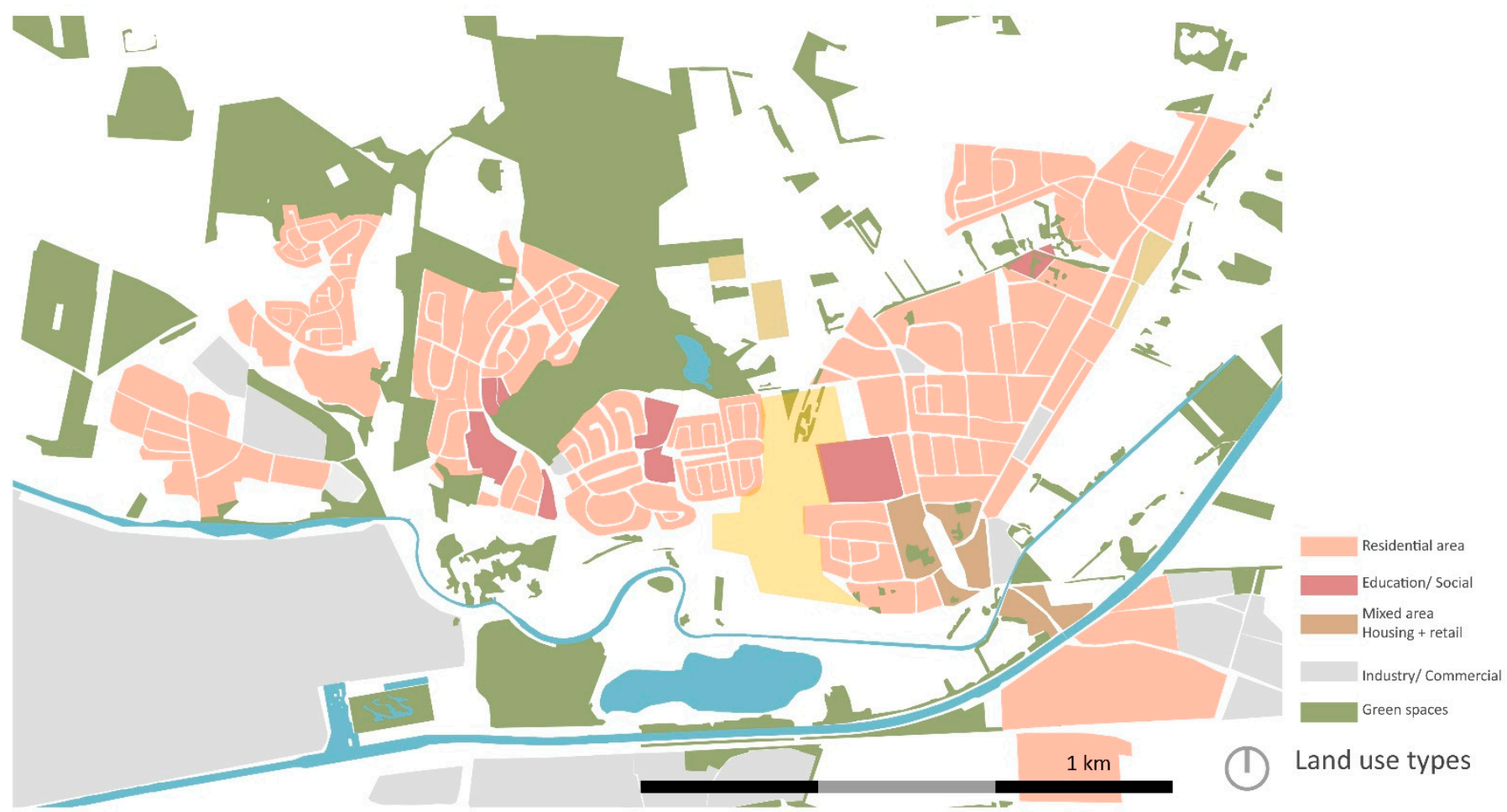

Figure 6. The settlements are situated at the urban periphery and represented mostly by residential areas submerged in the landscape. Own elaboration based on the digital ALKIS Stadtgrundkarte (2018) of the city of Wolfsburg.

The two core areas of Old Wolfsburg and Vorsfelde, which date back to the 17th century, are dominant structures of the northern part of Wolfsburg. Solitary building structures that were distributed throughout the area are represented by spacious educational facilities and sports infrastructure.

The western side of the district was created after 1950 and is typologically represented by attached and detached houses. This district is embedded in greenery and has a high proportion of open space structures (private gardens, community green). The settlement area of Vorsfelde is marked by mixed building types. The areas of single/multi-family houses, attached houses, as well as special typologies, e.g., knitted out by so-called carpet houses can be found here (Figure 7). 


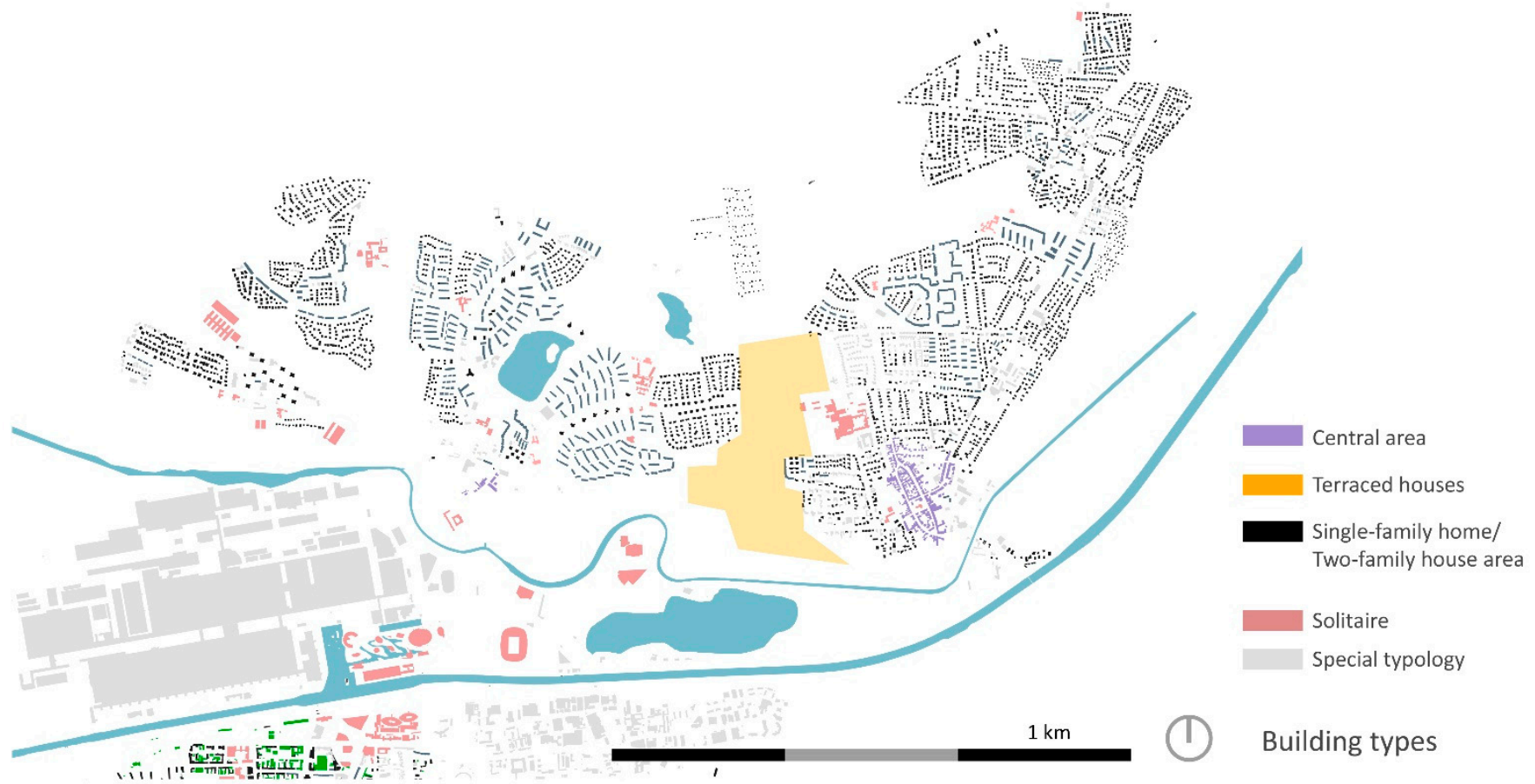

Figure 7. The urban area is characterized by a low density with a carpet made of blocks of flats (maximum 3-4 floors) and detached houses. The yellow area-the planning site/study area. Own elaboration based on the digital ALKIS Stadtgrundkarte (2018) of the city of Wolfsburg.

Several green and ecological corridors lead through the city. One of the most important green connections is formed by the floodplains and waters of the Aller, Allersee and Mittellandkanal rivers, which act as a distinctive link between the north and south of the city. Around $60 \%$ of Wolfsburg area consists of green and open spaces (Figure 8 ), and some of their main characteristics were often decisive when it comes to the location of new settlements (e.g., Klieversberg-Kliever Mountain or Waldsiedlung — "Forest settlement" in the southwestern part of the city). Forests and floodplains play an enormous role in the urban landscape. The arable land, which is 'right in front of the door' of the residents, shapes the overall image of the area. 


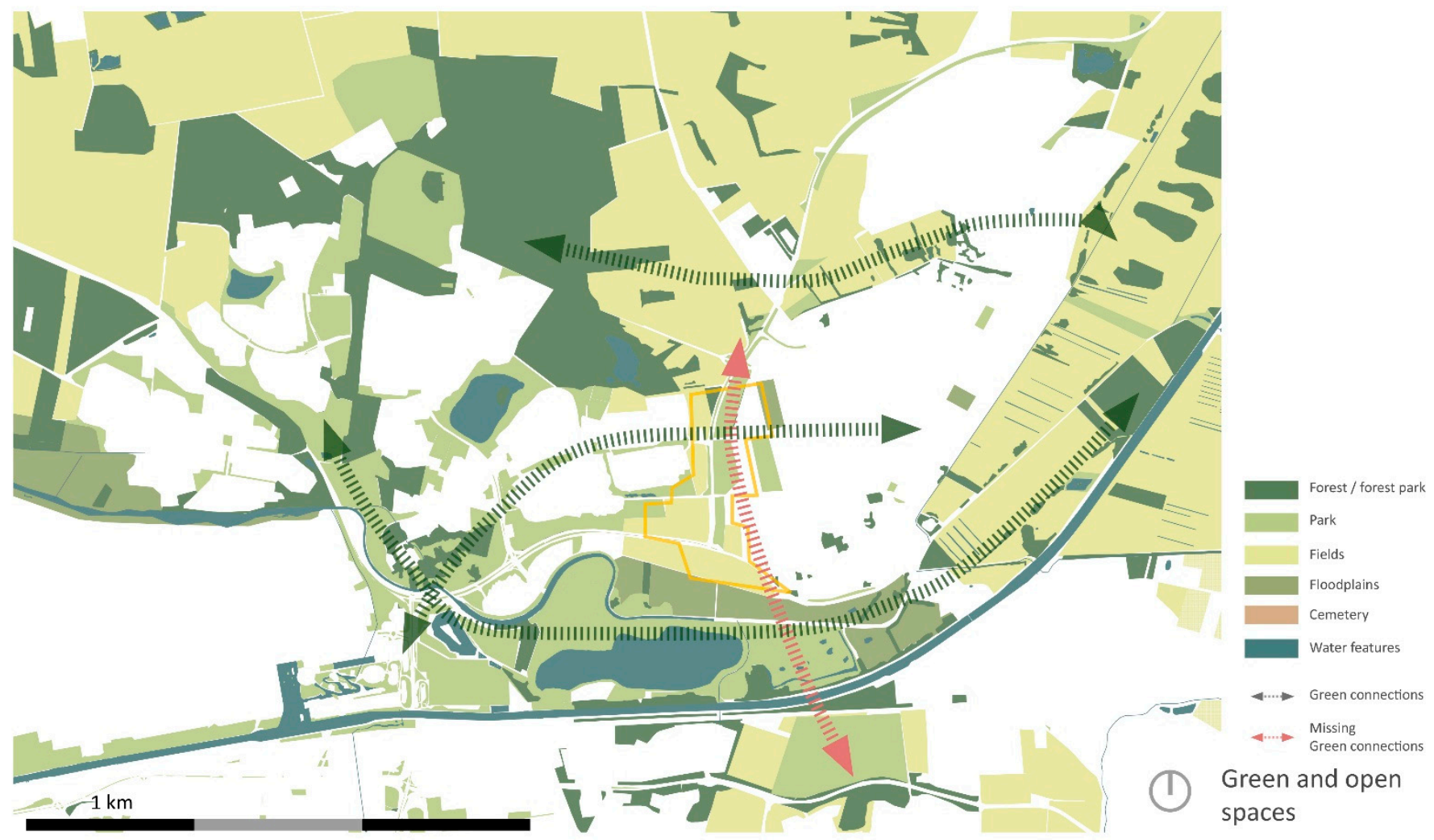

Figure 8. The city of Wolfsburg is rich with diverse green and open spaces and already has some existing ecological interconnectedness. Nevertheless, the north-south axis seems still to be undefined and requires a rational and programmed solution. Own elaboration based on the digital ALKIS Stadtgrundkarte (2018) of the city of Wolfsburg.

The quality of the existing urban landscape in the study area does not have a consistent sequence of rooms and clarified open space typology. Therefore, it remains unattractive for the potential users with regard to the facilities available. Currently, these areas exist as wasteland or replacement planting for the already built investments. It is essential to include these new green areas into the ecological corridor in the west-east direction. The new quarters should not completely close the development gap in the north-south axis but should offer a rich program by creating an additional connection to the southern part of the city. As a result, the affected open spaces are activated to strengthen the coherence of the city and bring both banks closer together.

The cityscape was strongly influenced by the cultural landscape (Figure 9). The historical development of the northern part still shows the old connection between AltWolfsburg and Vorsfelde and results in the "Historical Axis", which is also linked to the course of the Aller. In order to create the coherence of the northern part of the city, it is necessary to bridge the development gap (design area) along this axis and to give this area a clear identity. This would result in getting a compact settlement structure in the overall picture. 


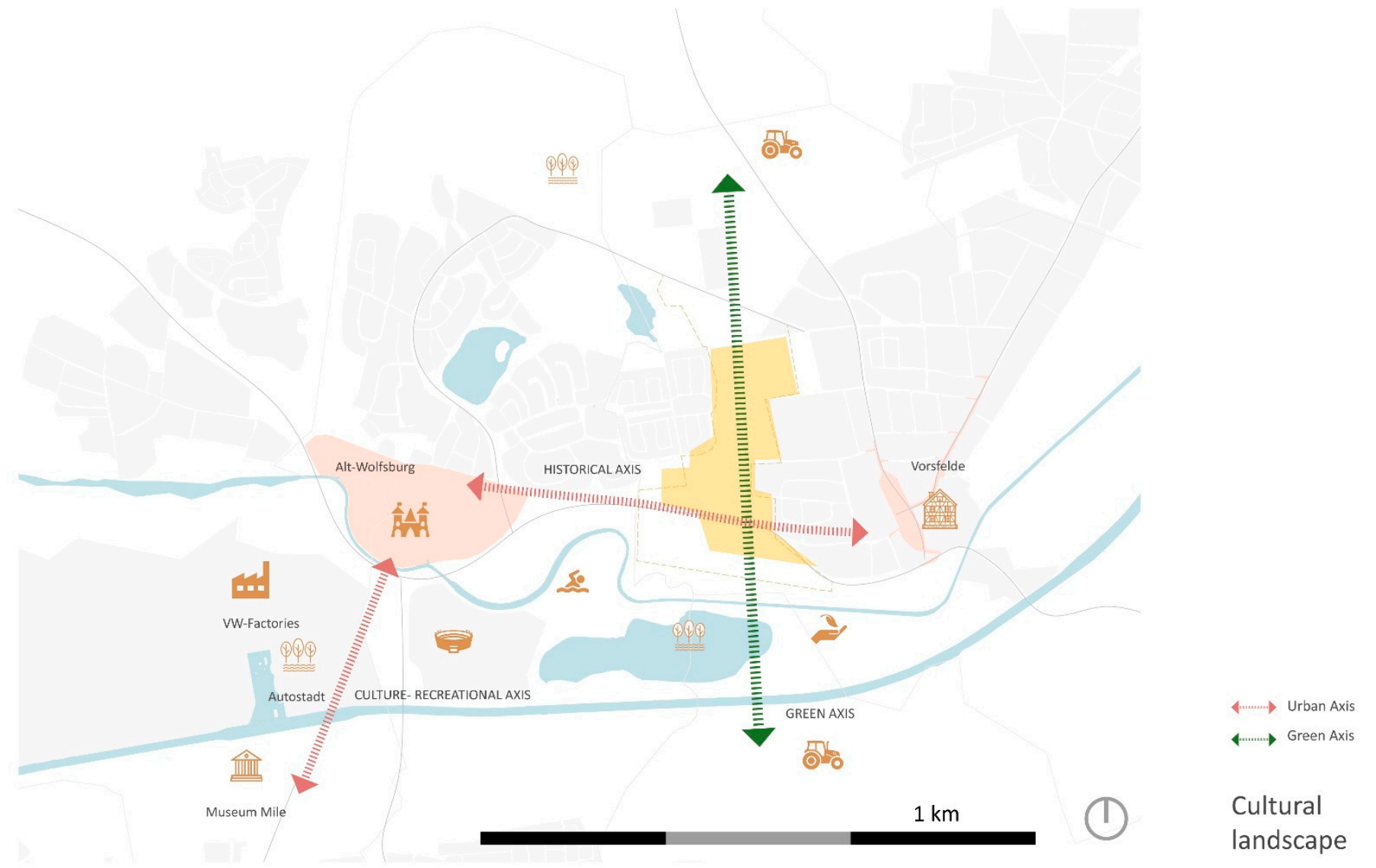

Figure 9. Cultural landscape of Wolfsburg. The "Historical Axis" connects the Alt-Wolfsburg with Vorsfelde, the "CultureRecreational Axis" connects the Alt-Wolfsburg and Porsche Street, and the "Green Axis" is to be strengthened. Own elaboration based on the digital ALKIS Stadtgrundkarte (2018) of the city of Wolfsburg.

With the creation of the "Green Axis", an additional un-urban connection with the southern part of the city could be created, which is intended primarily for pedestrians or cyclists (no traffic connection) and should activate one of the most important open spaces in the city.

The "Culture-Recreational Axis", which was already designed in 1938, extends between the castle and Porsche Street (nowadays a pedestrian zone). Further south, it opens the "Museum and Culture Mile" with the city's landmarks: phaeno by Zaha Hadid, library by Alvaro Aalto or Scharoun's Theater am Klieversberg.

Furthermore, the cultural heritage should be strengthened in the north-south line, mostly by the tools of intelligent, Ecological Urbanism which allows the green infrastructure to create a sustainable solution within the urban tissue.

The federal road that runs through open spaces is currently a significant source of the noise. The development of the road space at the mouth of the country road will reduce traffic frequency and noise at the same time. The reduced speed on the city promenade will improve living conditions and minimize noise. The road permeability is additionally supported by two parking garages, which are intended to accommodate commuter traffic at the entrance to the city and support other mobile routes.

The ultimate goal should be the creation of a new, integrated urban area within the city boundaries based on long-term solutions. It ought to create sustainable open spaces as a part of an urban design with a cultural heritage background. Wolfsburg is rich with diverse green and open spaces and already has some existing ecological connections. Nevertheless, the north-south axis is still undefined and seems to require a rational and programmed solution. 


\section{Results}

The task of this elaboration is to create coherence in the northern part of the city, to strengthen the edges and to create an uniform panorama image as well as attractive urban spaces. Strengthening of the precinct through infrastructural and green networking with innovative means of mobility and urban planning solutions supports the approach of the car-poor city, which should represent an antithesis to the previous car-friendly one.

\subsection{Conceptual Guidelines}

The main idea for the new district is to create coherence as an antithesis to the previous urban development (living separate from work, recreation and networking). Closing the edges of the space as a whole and emphasizing the building through a mix of typologies act as the foundation stone for coherent urban development. The functional mix: combining living with relaxation and work on a superordinate level as well as improving the infrastructural networking are guarantees for the all-round development of new quarters. Embedding in the landscape creates the backdrop and shapes the overall picture of the new district. Many forests and parks, moats, a very high proportion of agricultural land (relevant for self-sufficient food supply) and floodplains with their moat network shape the character of the district and are a contribution to Ecological Urbanism.

On the figure ground plan (Figure 10), it can be seen that the new precinct bridges a considerable gap between existing patchwork-like settlement islands and acts as an antithesis of Wolfsburg's urban development as a car-friendly and functional city. The open space plays a major role-the existing areas are reformulated and offer a mixture of buildings and valuable free spaces. Missing avenues are added in existing districtsVorsfelde and Bürgerkämpe and further towards the castle-in order to emphasize the sequence of rooms and to guarantee the continuity of the ecological corridors. New building forms fit into the gap creating coherence and a clear settlement structure in the northern part of Wolfsburg.

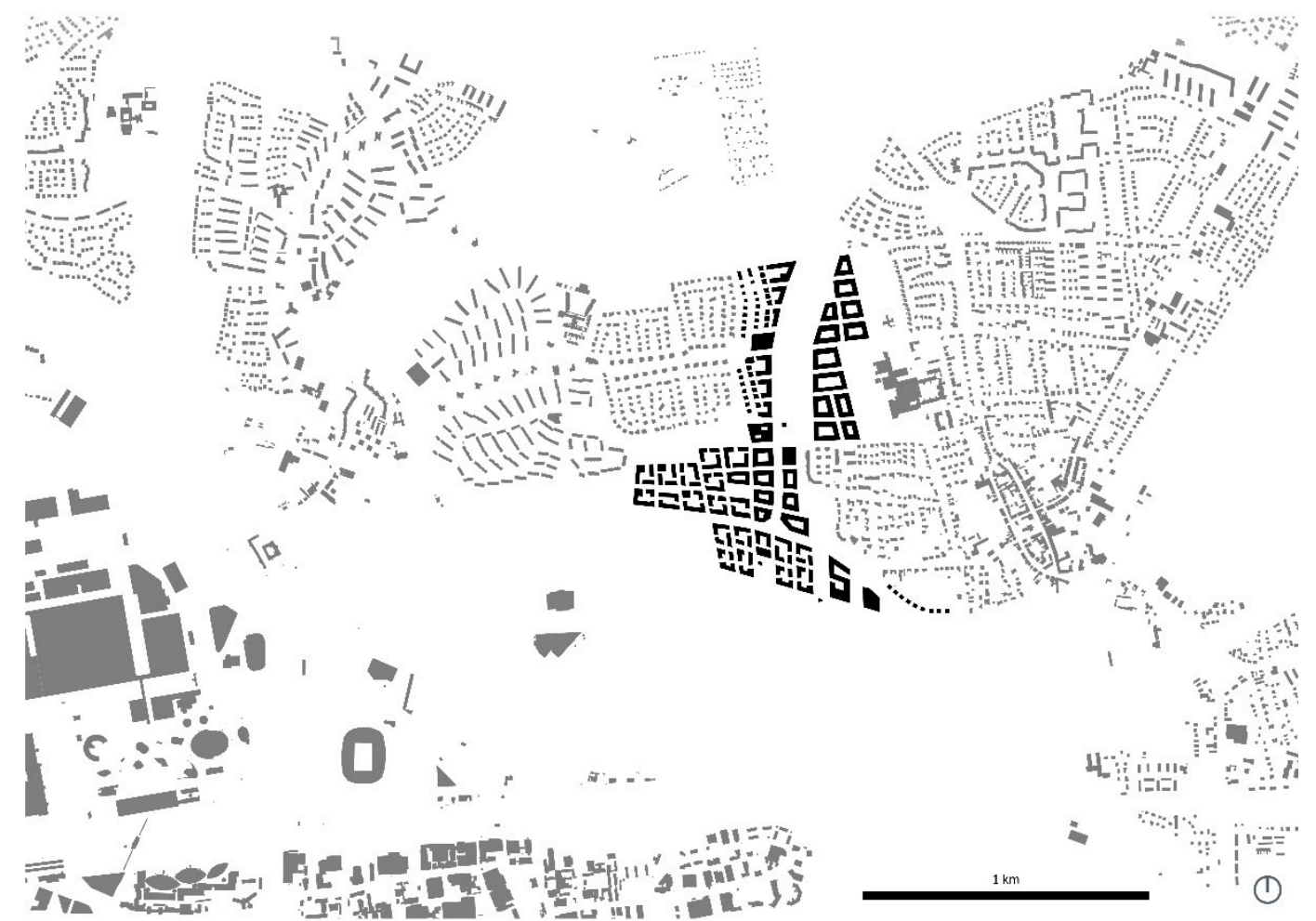

Figure 10. Figure ground with the new neighborhood. Own elaboration based on the digital ALKIS Stadtgrundkarte (2018) of the city of Wolfsburg. 
The overarching green corridor is reformulated with several open space types and offers a sequence of open spaces for the use of residents and guests. The area entrance is emphasized by selective high-rise buildings in the north and south and, thus, creates an opening to the landscape. The new district is orientated and linked to two differently formulated axes (Figure 11). The first, "Urban", is seen as the city promenade and is directly connected with the outside area of the daycare center in the south. The parallel "Green" leads through the open space with a wealth of leisure activities and ends in the balcony area in the south. The link with the Wolfsburg city center in the south is indicated and, at the same time, the edge of the new district on the northern side of the river Aller is marked.

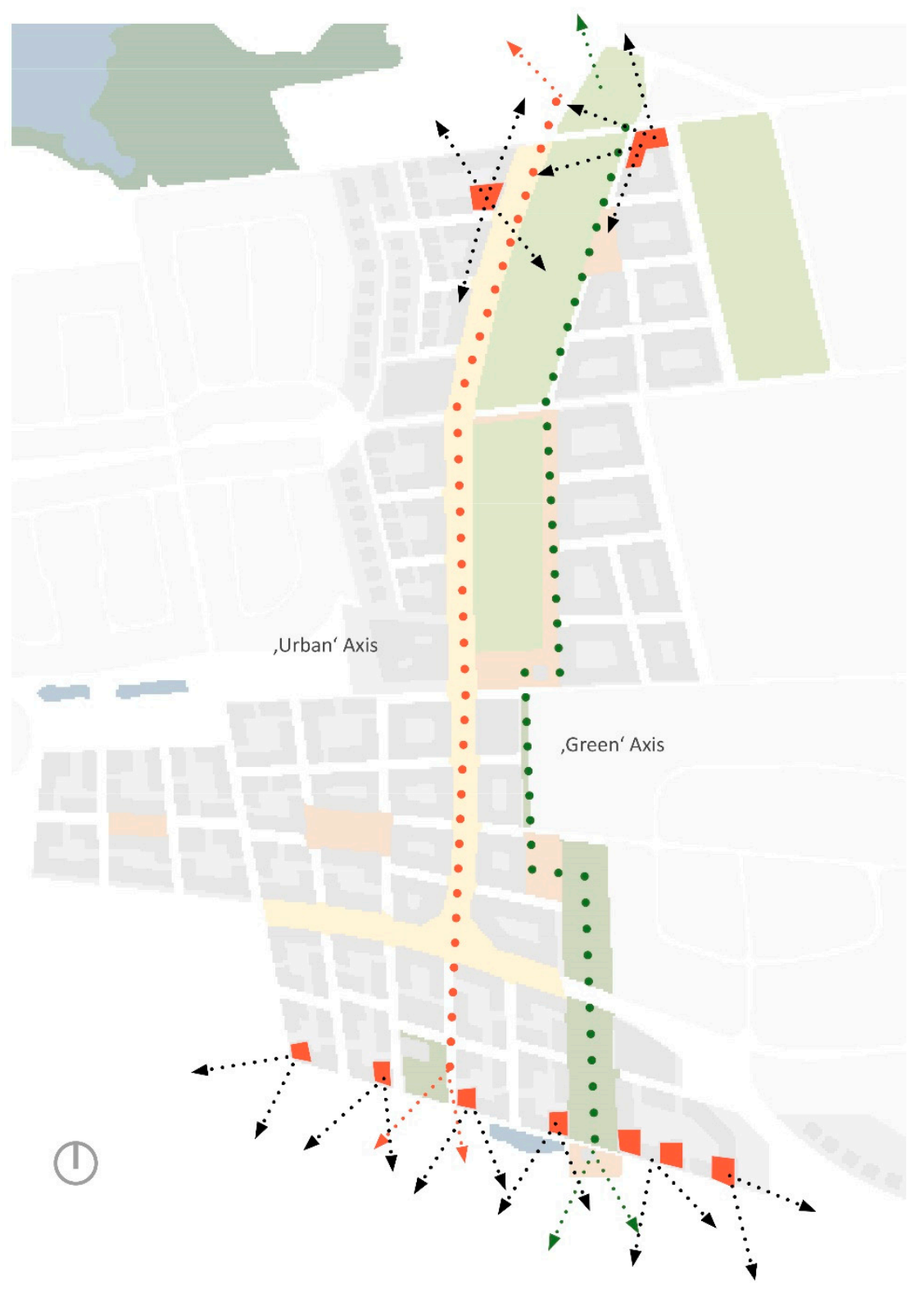

Figure 11. The two new Axes of the new neighborhood. The entrance area is emphasized by selective high-rise buildings in the north and south-opening into the landscape. The free space axes (1) the red one: "Urban Axis", as a city promenade, ends with the outside area of the day care center (2) the green one: "Green Axis", as a green corridor, as a parallel-ending with a park and a floodplain balcony. Diagram, without a scale. Own elaboration based on the digital ALKIS Stadtgrundkarte (2018) of the city of Wolfsburg. 
The design of free spaces (Figure 12) is understood as a network of open spaces, where each area has a different use and function. The urban park serves as the main outdoor salon of the new district. The leisure offer is the richest here. Starting with the head-district square with multifunctional space, playrooms for children (water/playground, climbing equipment, etc.) and adults (boules, table tennis, etc.). The spacious park trees provide shade, the grassy area invites to linger. The pedestrian zone located on the eastern edge of the park gives the opportunity to spend a quiet time as well as to go cycling or roller skating. This area is well maintained and functions as the center of the district.

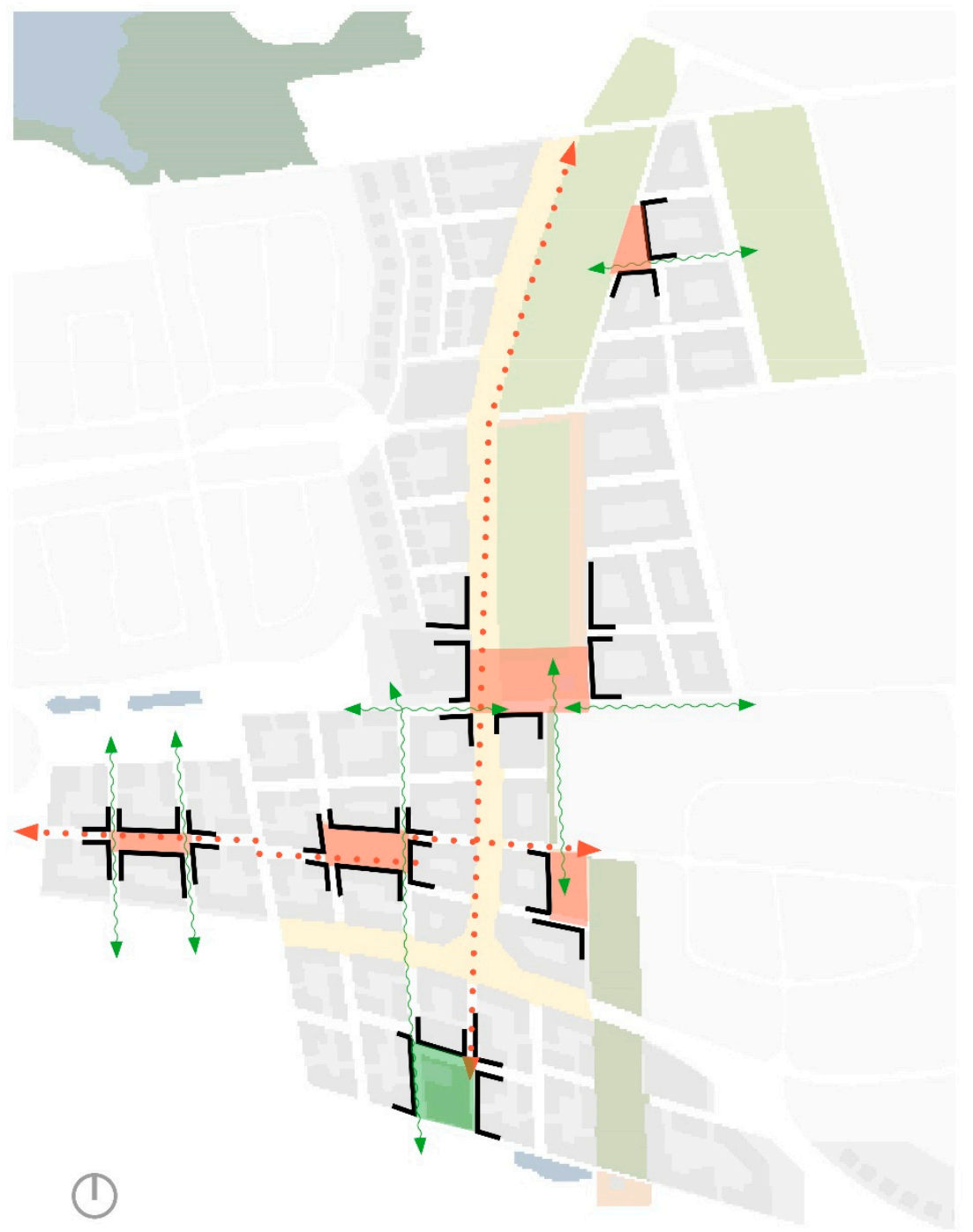

Figure 12. The concept of the new neighborhood squares is based on the networking of the neighborhood squares in the direction of N-S and W-E. A sequence of a Park-Plaza-Open space is supported by the networking of the open spaces (different types of program). Diagram, without a scale. Own elaboration based on the digital ALKIS Stadtgrundkarte (2018) of the city of Wolfsburg.

The orchard is mowed a maximum of two times a year, thus creating the best conditions for a flower meadow to grow. Fruit trees with edible fruits bloom here and provide shade on hot summer days. This community area is located directly next to the retirement home and can be maintained with the help of the residents. Everyone is invited to take part.

The square in the Farmers District can be made available for weekly markets with local and regional products. This strengthens togetherness and belonging to the region and the city. 
The park at the Water District is laid on existing retention basins. The identity is emphasized by the new planting of white willows (Salix alba L.) and reinforced by water playgrounds for children and nature trails.

The network of the open spaces in the precinct has its accumulation with the balcony plaza in the Field District. This is not only a square with a small café and playground for children, but also a connection to the hiking and cycling path that goes over the Aller River and Mittellandkanal and is intended to connect the southern and northern parts of the city.

The new squares play an important role in the neighborhoods/units as meeting places and fit into the existing green spaces. Their networking in the north-south and west-east direction is supported by the sequence of different urban landscape types and strengthened by different attractions.

The edges of the new precinct are in line with neighboring open spaces (Figure 13). This highlights the densification of the district in the northern area through closed blocks of flats and spacious parking areas. The networking of the open space is accompanied and guided by the street space (city promenade and pedestrian zone also as a parking space). The Field District opens up to the Aller Park: towards the south with partially open inner courtyards, in the north the opening followed by the Water District.

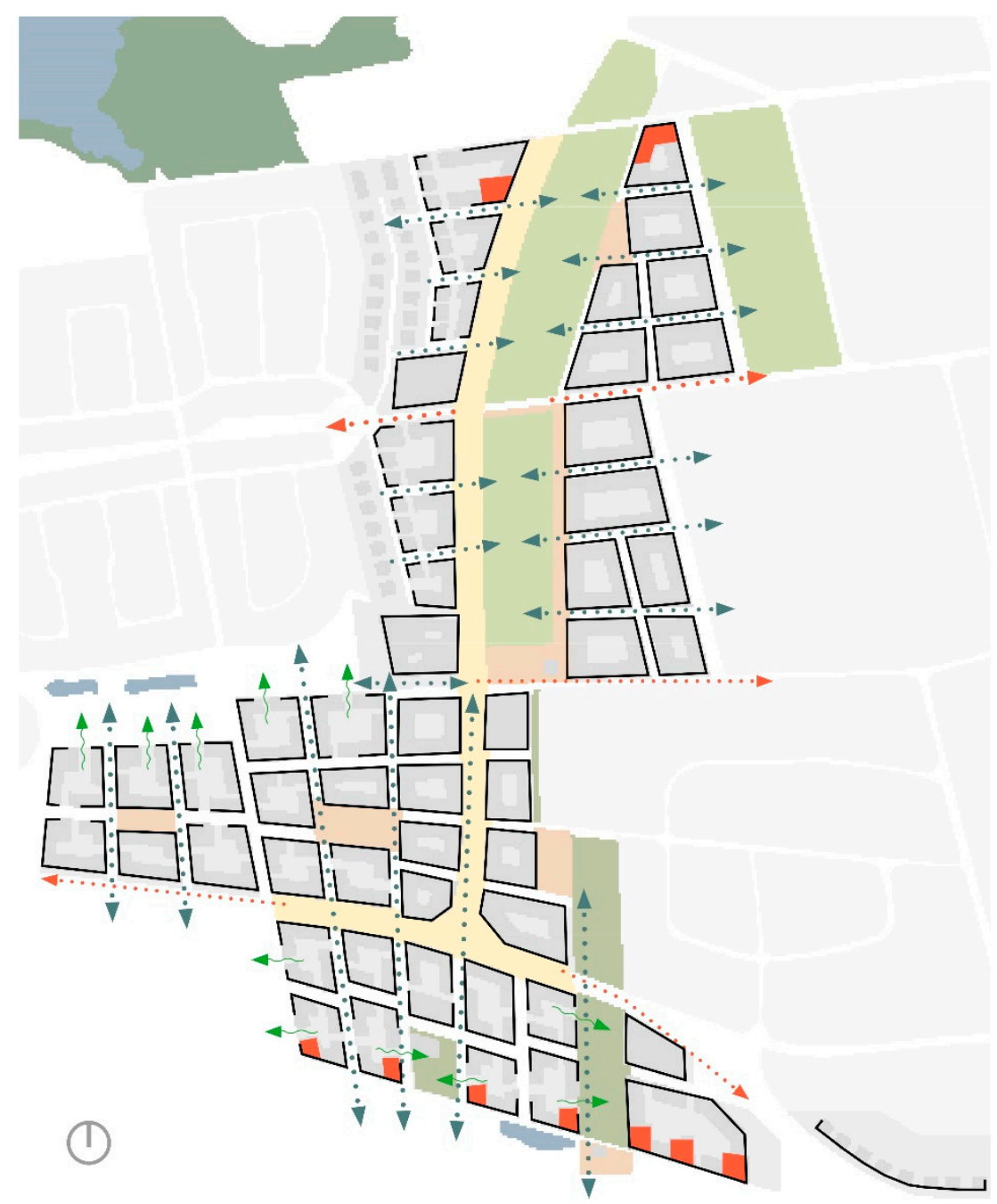

Figure 13. The edges of the built-up space and relation to the landscape. A significant densification of the district in the northern area (closed blocks); interconnectedness between the green/open and the street spaces. The Field District and Water District open onto the open space to the south and north. The courtyards are partly opened. Diagram, without a scale. Own elaboration based on the digital ALKIS Stadtgrundkarte (2018) of the city of Wolfsburg. 


\subsection{Urban Structure and Quality of Open Spaces}

The formulation of four differentiated District (Figure 14) with clear spatial delimitation makes up the overall picture of the precinct: in the north and south, there is a strong reference to the surrounding landscape, in the west and east existing structures are connected. It is important to interlink with very distinctive landscape structures such as agricultural fields, floodplains, as well as the belt of forests and parks, which play an important role for the residents as open and recreational areas. The superior ecological corridors are re-formulated for the greatest added value of the space. The centrally located urban park connects the areas of Vorsfelde and Bürgerkamp, which have been expanded accordingly in terms of urban planning, and connects them with a district square. A maximum density is intended to be reached on the park side and on the main street (city promenade) - this should be achieved with strong, closed and space-forming structures as well as many public and community areas. This appears to be the best location in the whole district. The prominent high points reinforce the key positions and provide orientation points for the sequence of urban spaces.

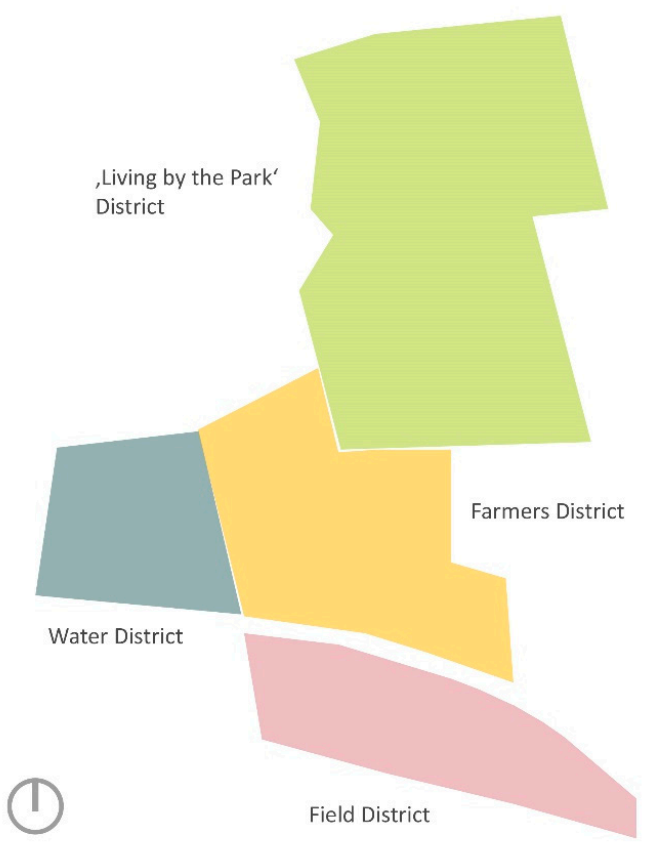

Figure 14. The New Districts of the study area, diagram, without a scale. Diagram, without a scale. Own elaboration based on the digital ALKIS Stadtgrundkarte (2018) of the city of Wolfsburg.

The southern districts offer looser and open development with a very strong relationship to the landscape and more private open spaces within the block.

In the Water District (Wasserquartier), residents will not only be able to enjoy the differentiated building types, but also a considerable proportion of private gardens. In the construction site, there is only one maintenance path for economic and maintenance reasons. The communal areas are located in surrounding parks and spacious quarters.

In the Field District (Auenquartier), residents are given the same share of private space. In addition, they have extensive floodplain landscapes as well as parking areas and playgrounds in front of their houses.

The Living by the Park District ("Wohnen am Park" Quartier) with its dense development offers communal areas within the block as inner courtyards. This is the place of rest, retreat and coexistence. In addition to the fairground with a high proportion of restaurants, the newly designed park also offers public play areas with a wide range of leisure activities. The new single-family home area is enriched with private gardens. 
This is what defines the special character of each District and creates differentiated atmospheres and spatial types with correspondingly high density and building typologies that are as manifold as possible.

The ultimate goal is to develop a lively, sustainable and mixed development concept for the whole precinct (Figure 15).

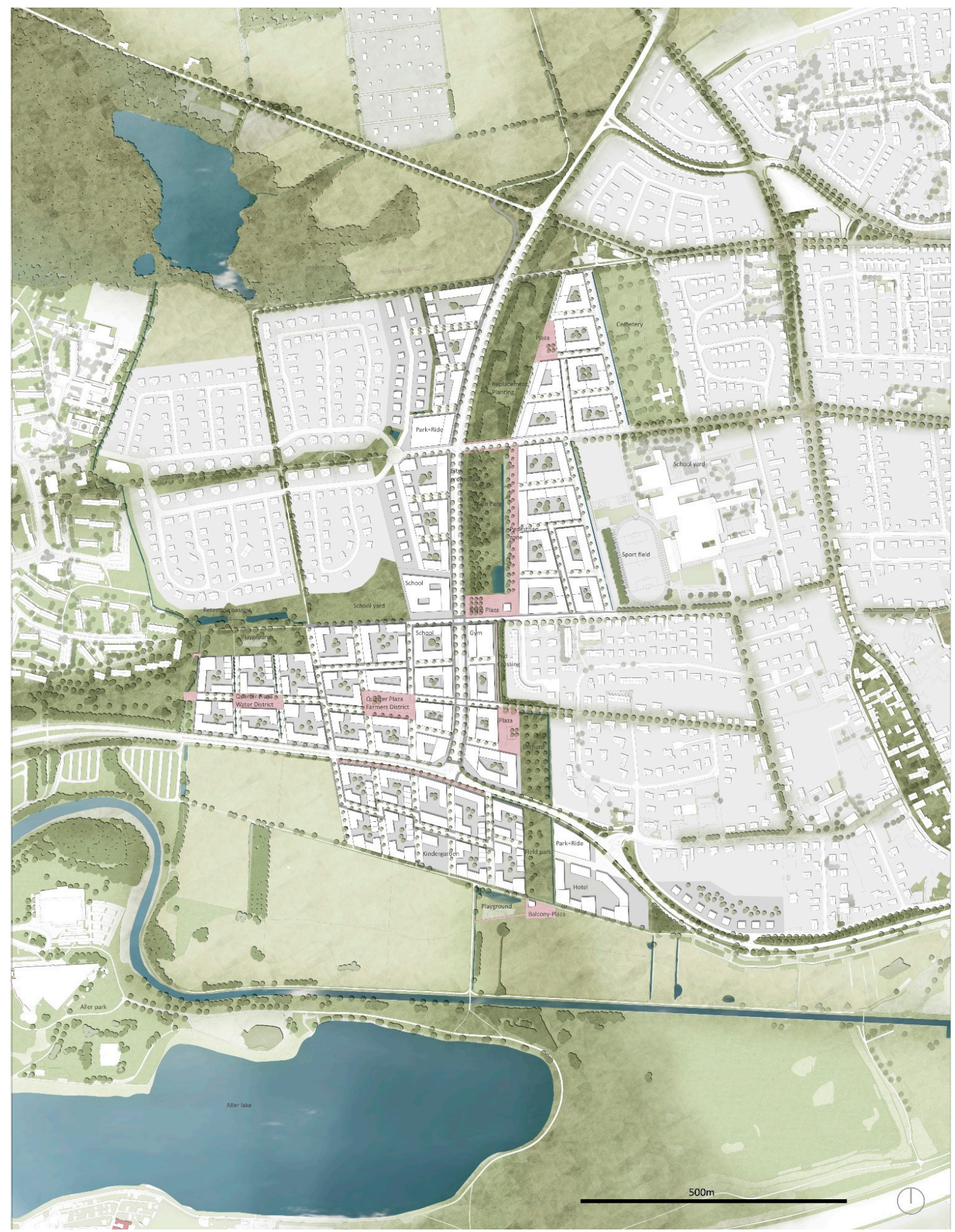

Figure 15. Conceptual proposal for the study area. Own elaboration based on the digital ALKIS Stadtgrundkarte (2018) of the city of Wolfsburg. 
The new precinct can be seen as a model plan for the future development of Wolfsburg. The goals of town planning concentrate on creating an anti-car city, unlike before, with the help of multifunctional means of transport and reducing traffic (dismantling a stretch of the L291 highway, residential street, residential path, and walkability). Creating an attractive place to live and work is an overarching theme. The new residents should be able to enjoy differentiated and attractive open spaces and their interconnectedness. The strengthening of self-sufficiency through the use of an "edible" city, the variety of native tree species and biological diversity answer the questions of sustainability and climate friendliness (resiliency). The concept of the walkable city of short distances is supported by an urban mix (vertical and horizontal) and intelligent urbanity.

The new intelligent and environmentally friendly transport concept (Figure 16) is intended to support the redevelopment of the precinct and represents the opportunity to focus on climate-friendly and adapted means of mobility. The goal is to create mixed mobility that also takes into account previous, traditional car models and partially car-poor areas. Alternative means of transport such as electromobility (E-Bike, and E-Car) is of particular importance for the Wolfsburg-Braunschweig region, which has been shaped by automotive history. Future issues such as energy generation, the expansion of the charging station network but also the use of electric vehicles should influence the further development of the city.

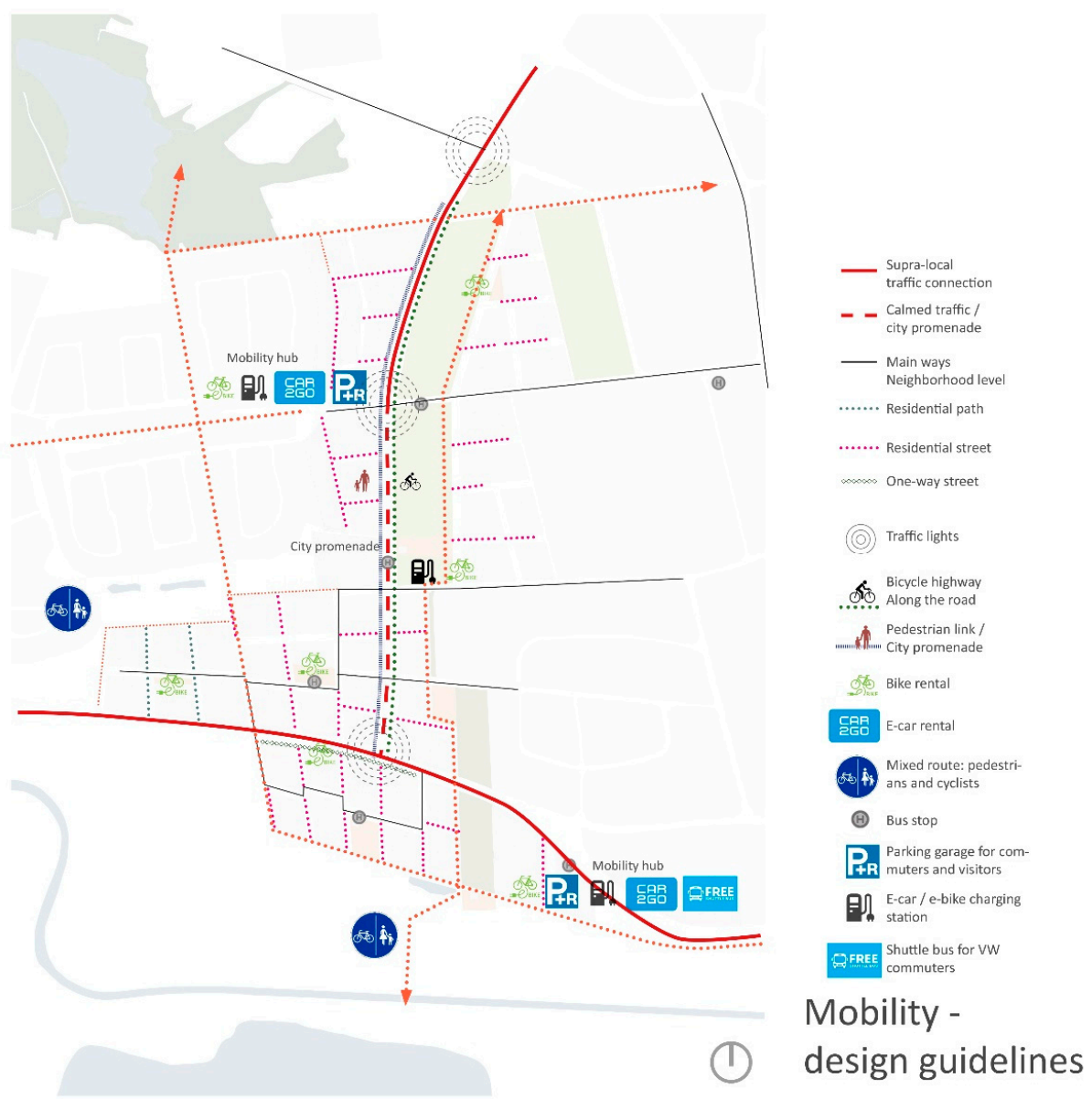

Figure 16. Mobility concept for the study area is based on the two mobility hubs located in the eastern and northern part of the study area. Their aim is to collect the commuters before entering the city area. The mobility should be strengthened with the pedestrian zones and cycling paths. Diagram, without a scale. Own elaboration based on the digital ALKIS Stadtgrundkarte (2018) of the city of Wolfsburg. 
The new area should be planned as sustainably as possible. The main design idea to create the new urban landscape is based on the existing structures such as moats or oak avenues, which should be implemented in the further planning process. The planting of new districts should reflect the variety of local tree species and, thereby, support fauna and flora. Fruits can be partially edible (orchards with apples, fruit trees in the private garden). Specially selected local tree cultivars give the urban animals the opportunity to find food on site during the winter or early spring when there might be a shortage of food. Trees were selected according to what they are used for, resulting in the following categories: avenue trees (pedunculate/English oak-Quercus robur L., Norway mapleAcer platanoides L., small-leaved lime-Tilia cordata Mill., honey locust-Gleditsia triacanthos L., gray alder-Alnus incana (L.) Moench), trees with edible fruits for animals (serviceberryAmelanchier lamarckii, rowan-Sorbus aucuparia L., horse chestnut-Aesculus hippocastanum L., locust-Robinia pseudoacacia L., pedunculate/English oak-Quercus robur L., rowanSorbus aucuparia L., small-leaved lime-Tilia cordata L., white willow-Salix alba L.), park trees (common beech-Fagus sylvatica L., horse chestnut-Aesculus hippocastanum L., locustRobinia pseudoacacia L., small-leaved lime-Tilia cordata Mill.). The representative city promenade and other main avenues, also in the existing neighborhoods, are accentuated by pedunculate/English oak-Quercus robur L., which is very characteristic in this area. The Water District is characterized by the use of moisture-loving trees (white willow-Salix alba L., gray alder-Alnus incana (L.) Moench). Honey locust-Gleditsia triacanthos L. will be characteristic in the Field District. The heavily blooming rowan-Sorbus aucuparia L. and bird cherry-Prunus avium L. sprinkle the orchards and courtyards in the Farmers District; here the small-leaved lime-Tilia cordata L. exudes a strong aroma and provides food for the bees. Park trees characterize the Living by the Park District - the small-leaved lime dominates here as an avenue tree, other tree species such as common beech, horse chestnut and robinia reinforce the Urban Park. Juneberry and rowan berries bloom in the inner courtyards. The edible city is home for the young and the old.

Intelligent urban design integrates cohesively existing settlements and bonds the northern and the southern parts of the city. The sustainable, ecological interconnectedness has been strengthened through the mixed vertical and horizontal use, landmarks, diversified program of the green and recreational spaces, and alleys along the traffic routes. Biodiversity is emphasized with distinctive biologically active green spaces and a variety of species (trees and animals).

\section{Discussion}

The Principles of Intelligent Urbanism and Ecological Urbanism emphasize different aspects of sustainable urban development. They also agree on some points and set similar goals to be achieved. They both contribute to the prevention of urban sprawl and creation of a compact city. The Principles were taken into account into initial phase of the project (identification of design problems) and implemented in the conceptual proposal for the city of Wolfsburg.

The solutions to the problems of the overcrowded and polluted city of the end of the 19th century described by a number of authors as the construction of towns or settlementsgardens were also implemented in Wolfsburg at the turn of the 1930s and 1940s. It can be evidenced by the dispersed development of the central district or Steimker Berg. In the urban structure of Wolfsburg there is also a clear division into residential and industrialproduction parts. It is rooted in the 1960s concept of an organic-scattered city. These three historical factors described by Schubert, Angelidou, Chmielewski, Lynch, Howard, Mumford, Nechyba, Black, Osborn, and others, contributed to the sprawl and inconsistency of today's city. It can be concluded that the period particularly responsible for this phenomenon has its origin in the second half of the 20th century, which seems to be parallel with the trends of European cities. What Wolfsburg can be distinguished for is the scale of this dispersion. 
The proposal from Mostafavi of basing the ecological urban planning on biodiversity and introducing the idea of urban gardening and 'edible city' was considered possible and justified to implement in the design concept. Various tree species were selected based on the microclimate conditions and their utility for humans and the city animals. This strengthens biodiversity on the micro and macro-levels, creating an 'edible city'. It shows that the Principles of Ecological Urbanism mentioned in this study have been successfully implemented in the conceptual proposal. The infrastructural elements (blue infrastructure) like water retention on site and delayed water drainage are crucial and must be mentioned. The Principles of Intelligent Urbanism such as balance with nature, regional integration and vision have been, therefore, also accomplished.

Similarly, the conditioning of the sustainable growth of the urban areas was recognized as one of the elements of the individual cultural and landscape values along with the respect for the tradition of the place [26,31-33]. It was considered as the basic element indicating the direction of the development of the new spatial order. This principle was implemented by highlighting Wolfsburg's historical axes or the urban scale of the newly designed neighborhoods.

Intelligent Urbanism focuses on the sustainable use of the balanced movement: welldefined streets, provision of cycle paths as a contribution to public transport, hybrid transportation, and implementation of electromobility. The width of the new streets was hierarchized and provided the opportunity for walkability and sharing space. The imperfection of using e-mobility is based primarily on the introduction of the appropriate infrastructure (charging stations, subsidies for the solar panels, e-car, and e-bikes), which can basically be implemented only in the richest countries. This Principle can be, therefore, considered to be non-universal.

The main social goal was to develop a sense of community among residents. It was possible thanks to the application of Principles from both systems. In this matter, amenities and social facilities were located centrally in the new neighborhood unit or alongside main traffic arteries. Moreover, there are such elements as a vibrant building structure, private gardens, and access to green and open spaces. One can find areas for recreation and social interactions. This approach is in harmony with the existing conditions of the green urbanscape. Moreover, the central Allerpark has become a connecting element between both sides of the city. Its eastern zones have been, thanks to this design, activated and they offer new amenities. The biggest structural infrastructure is based on the interconnectedness of the system plaza-park, which, on a city level, helps sustain the north-south and west-east ecological corridors.

Ecological and Intelligent Urbanism share the idea that the local government should participate in the recovery process and coordinate it with a top-down approach. Alternatively, it can be mentioned that, at the design stage, such an assumption could have been made.

The city of Wolfsburg was lively interested in creating a new neighborhood for the commuters of the VW plant. However, it is difficult to discuss the social role of this project and whether there was a reaction of the local community to such changes. It would require the implementation of this case study and, above all, the further involvement of the local government and residents through social consultations. This conceptual proposal is a kind of an opportunity, a first step towards further development strategy. Any actions undertaken by the city would take into account the future residents. For objective reasons, the strengths of this study can be indicated as follows: it is possible that this proposal could be used in future works on city development strategy, so that it could be considered for the implementation as a platform for the future talks between local authorities, planners, and architects with the city residents about the further shape and functions of the city of Wolfsburg. The results and conclusions should correct the presented plan, thanks to which there is a chance for its full or partial implementation. The case study of Wolfsburg was not ordered for implementation purposes. 
The goal of developing a repair model of Ecological and Intelligent Urbanism has been, at this planning stage, achieved. It offers a rational and sustainable development plan for urban areas.

\section{Conclusions}

The aim of this study was to create coherence for the northern part of the city and to suggest a new direction in the urban development for the city of Wolfsburg. The previous patchwork family of the settlement islands competed with landscape structures-the new quarter bridges the urban gap, strengthens the building structure of the city as a whole and creates clear urban edges. The northern part of the city was redefined and connected to the city center in the south through the spacious central park with Allersee and Allerpark. The new neighborhood is sustainably planned and can be integrated into the existing structures with the help of the infrastructure (streets and avenues) and open spaces (parks, orchards, playgrounds, plazas, and tree alleys) found in the transitional area. The new quarters will be sprinkled with local squares and communal areas and strengthen the local community. New residents and users will be given multifunctional mobility options as well as transport possibilities. The designed urban concept enables also the implementation of innovative means of electromobility. They are operated as environmentally friendly as possible thanks to the energy that is produced on site (solar panels, and wind energy). The green areas are planned to be inclusive and rich in programs to create a vibrant urban life and interaction with the landscape. Additional green spaces on roofs emphasize the relationship to open space and social life.

The new, integrated urban area is nothing like the existing suburban situation. This proposal rejects the idea of scattered, undefined urban and landscaping structures. The new infill with a denser architecture and green infrastructure offers a mixed use of open spaces and building forms. This coherent and meticulously planned urban development ensures intelligent growth and implements the tools of ecological urbanism as an offer for sustainable landscape architecture.

Author Contributions: Conceptualization, J.D.-K. and B.W.; methodology, J.D.-K.; validation, J.D.-K. and B.W.; formal analysis, J.D.-K. and B.W.; investigation,. J.D.-K. and B.W.; resources, B.W.; writingoriginal draft preparation, J.D.-K. and B.W.; writing-review and editing J.D.-K. and B.W.; visualization, B.W.; supervision, J.D.-K.; project administration, J.D.-K. and B.W. All authors have read and agreed to the published version of the manuscript.

Funding: This research received no external funding.

Institutional Review Board Statement: Not applicable.

Informed Consent Statement: Not applicable.

Data Availability Statement: Not applicable.

Acknowledgments: To the head Professor Heinz Nagler from the Chair of Urban Design at the Brandenburg University of Technology Cottbus-Senftenberg in Germany, for the inspiration for this article.

Conflicts of Interest: The authors declare no conflict of interest.

\section{References}

1. Schubert, D. Cities and plans-The past defines the future. Plan. Perspect. 2019, 34, 3-23. [CrossRef]

2. Angelidou, M. Smart cities: A conjuncture of four forces. Cities 2015, 47, 95-106. [CrossRef]

3. Basiri, M.; Zeynali Azim, A.; Farrokhi, M. Smart City Solution for Sustainable Urban Development. Eur. J. Sustain. Dev. 2017, 6, 71-84. [CrossRef]

4. Hall, P. Cities of Tomorrow: An Intellectual History of Urban Planning and Design in the Twentieth Century, 3rd ed.; Wiley-Blackwell: Hoboken, NJ, USA, 2002.

5. Chmielewski, J.M. Teoria Urbanistyki w Projektowaniu i Planowaniu Miast; Oficyna Wydawnicza Politechniki Warszawskiej: Warszawa, Poland, 2010. 
6. $\quad$ Lynch, K. A Theory of Good City Form; MIT Press: Cambridge, MA, USA, 1981.

7. Mumford, L. The neighborhood and the neighborhood unit. Town Plan. Rev. 1954, 24, 256-270. Available online: https: / / www.jstor.org/stable/40101548 (accessed on 27 December 2020). [CrossRef]

8. Cretan, R. Who owns the name? Fandom, social inequalities and the contested renaming of a football club in Timisoara, Romania. Urban Geogr. 2019, 40, 805-825. [CrossRef]

9. Howard, E. Garden Cities of To-Morrow; S.Sonnenschein \& Co., Ltd.: London, UK, 1902.

10. Garden Cities of Tomorrow. Available online: http://urbanplanning.library.cornell.edu/DOCS/howard.htm (accessed on 27 December 2020).

11. Komninos, N.; Pallot, M.; Schaffers, H. Open Innovation towards Smarter Cities. In Open Innovation 2013; European Commission, Directorate-General for Communications Networks Content and Technology: Luxembourg, 2013; pp. 34-41. [CrossRef]

12. Navigant Research. Smart Cities; Intelligent Information and Communications Technology Infrastructure in the Government, Buildings, Transport, and Utility Domains (Research Report). 2011. Available online: http://www.navigantresearch.com/ research/smartcities (accessed on 9 February 2012).

13. Schaffers, H. Empowering Citizens to Realizing Smart Cities: Results from FIREBALL Smart City Case Studies (presentation). In Proceedings of the 2012 Future Internet Assembly (FIA), Aalborg, Denmark, 10-11 May 2012. Available online: http: / / www.fiaalborg.eu/downloads/Session_1.1_Hans_Schaffers.pdf (accessed on 15 December 2020).

14. Wolfram, M. Deconstructing Smart Cities: An Intertextual Reading of Concepts and Practices for Integrated Urban and ICT Development. In Proceedings of the REAL CORP 2012, Schwechat, Austria, 14-16 May 2012. Available online: http:/ / www.corp. at/archive/CORP2012_192.pdf (accessed on 15 December 2020).

15. Litwińska, E. Modelling of metropolitan structure in aspect of urban sprawl. Tech. Transl. Archit. 2010, 1-A, 139-148. Available online: https:/ / repozytorium.biblos.pk.edu.pl/redo/resources/32875/file/suwFiles/LitwinskaE_ModelowanieStruktur.pdf (accessed on 15 December 2020).

16. Słodczyk, J. Wielkość miast i ich struktura przestrzenna w świetle kryteriów rozwoju zrównoważonego. In Przemiany Bazy Ekonomicznej i Bazy Przestrzennej Miast; Wydawnictwo Uniwersytetu Opolskiego: Opole, Poland, 2002; pp. 323-331.

17. Zuziak, Z. Ecological definition of urban sciences. Czas. Tech. Wydaw. Politech. Krak. 2007, 7-A, 9-20. Available online: https:/ / repozytorium.biblos.pk.edu.pl/redo/resources/34951/file/suwFiles/ZuziakZ_EkologiczneDefiniowanie.pdf (accessed on 15 December 2020).

18. Nechyba, T.J.; Walsh, R.P. Urban sprawl. J. Econ. Perspect. 2004, 18, 177-200. [CrossRef]

19. Black, J.T. The Economics of Sprawl. Urban Land 1996, 55, 52-53.

20. Osborn, F.J. Preface. In Garden Cities of To-Morrow; Faber and Faber: London, UK, 1946; p. 15.

21. Ewing, R. Is Los Angeles-Style sprawl desirable? J. Am. Plan. Assoc. 2007, 63, 107-126. [CrossRef]

22. Couch, C.; Leontidou, L.; Arnstberg, K.O. The origins of suburbia and urban sprawl in Europe and the USA. In Urban Sprawl in Europe: Landscape, Land-Use Change and Policy; Couch, C., Leontidou, L., Petschel-Held, G., Eds.; Blackwell Publishing Ltd.: Oxford, UK, 2007; pp. 6-14.

23. Mostafavi, M.; Doherty, G. Ecological Urbanism; Harvard University Graduate School of Design: Cambridge, MA, USA; Lars Müller Publishers: Baden, Switzerland, 2009.

24. Szulczewska, B. Zielona Infrastruktura-Czy Koniec Historii? Studia KPZK: Warsaw, Poland, 2019; Volume 189. Available online: http:/ / scholar.googleusercontent.com/scholar?q=cache:Yk0_4ZKW-EQJ:scholar.google.com/+szulczewska+barbara\& $\mathrm{hl}=$ pl\&as_sdt=0,5 (accessed on 27 March 2021).

25. United Nations. Available online: https://www.un.org/development/desa/en/news/population/2018-revision-of-worldurbanization-prospects.html (accessed on 12 February 2021).

26. Benninger, C. Principles of Intelligent Urbanism: The case. Ekistics 2002, 69, 60-80. Available online: https://about.jstor.org/terms (accessed on 4 January 2021).

27. O'Grady, M.; O'Hare, G. How Smart Is Your City? Science 2012, 335, 1581-1582. [CrossRef] [PubMed]

28. Caragliu, A.; del Boro, C.; Nijkamp, P. Smart Cities in Europe. In Proceedings of the 3rd Central European Conference in Regional Science-CERS, Košice, Slovacka, 7-9 October 2009; pp. 45-59. Available online: https://inta-aivn.org/images/cc/Urbanism/ background\%20documents /01_03_Nijkamp.pdf (accessed on 22 March 2021).

29. Sikora-Fernandez, D. Smart city jako nowa koncepcja funkcjonowania i rozwoju miast w Polsce. Res. Pap. Wrocław Univ. Econ. 2014, 339, 175-181. [CrossRef]

30. Ibanescu, B.-C.; Banica, A.; Eva, M.; Cehan, A. The puzzling concept of smart city in central and eastern Europe. Lit. Rev. Des. Policy Dev. Transylv. Rev. Adm. Sci. 2020, 61E, 70-87. [CrossRef]

31. Serag el Din, H.; Shalaby, A.; Farouh, H.E.; Elariane, S.A. Principles of urban quality of life for a neighborhood. HBRC J. 2013, 9 , 86-92. [CrossRef]

32. Principles of Intelligent Urbanism. Available online: https://missurasa.wordpress.com/2013/05/09/principles-of-intelligenturbanism/ (accessed on 27 December 2020).

33. Bugadze, N. Theory and Practice of "Intelligent Urbanism". Bull. Georgian Natl. Acad. Sci. 2018, 12, 145-151. Available online: https:/ / www.researchgate.net/publication/329908058_Theory_and_practice_of_intelligent_urbanism (accessed on 29 December 2020).

34. Rytelewska-Chilczuk, N. Rola architektury miejskiej w budowaniu tożsamości mieszkańców miast. Ogrody Nauk Sztuk 2018, 8, 224-233. [CrossRef] 
35. Nikitas, A.; Michalakopoulou, K.; Njoya, E.T.; Karampatzakis, D. Artificial Intelligence, Transport and the Smart City: Definitions and Dimensions of a New Mobility Era. Sustainability 2020, 12, 2789. [CrossRef]

36. Santoso, S.; Kuehn, A. Intelligent Urbanism: Convivial Living in Smart Cities. In Proceedings of the iConference 2013, Fort Worth, TX, USA, 12-15 February 2013; pp. 566-570. [CrossRef]

37. Iacomoni, A. European green capitals, Best practices for sustainable urban development. AGATHÓN Int. J. Archit. Art Des. 2019, 6, 114-125. [CrossRef]

38. Jopek, D. Intelligent urban space as a factor in the development of smart cities. Tech. Transl. Archit. Urban. 2019, 9, 5-15. [CrossRef]

39. European Green Capitals Call for Global Action. Available online: ec.europa.eu/environment/efe/news/european-greencapitals-call-global-action-2019-01-24_en (accessed on 30 September 2019).

40. Caragliu, A.; Del Bo, C.; Nijkamp, P. Smart Cities in Europe. J. Urban Technol. 2011, 18, 65-82. [CrossRef]

41. Ghezzi, P.; Daole, F.; Ottaviani, G. Pisa_Piantare Alberi per Mettere Radici_Città Resilienti, Infrastrutture Verdi; Paysage: Milan, Italy, 2017.

42. Wahlstrom, M.H.; Kourtit, K.; Nijkamp, P. Planning Cities4People-A body and soul analysis of urban neighbourhoods. Public Manag. Rev. 2020, 22, 687-700. [CrossRef]

43. Kourtit, K.; Nijkamp, P.; Wahlstrom, M.H. How to make cities the home of people-A 'soul and body' analysis of urban attractiveness. Land Use Policy 2020, 104734, 1-9. [CrossRef]

44. Kourtit, K. Cultural heritage, smart cities and digital data analytics. East. J. Eur. Stud. 2019, 10, 151-159. Available online: https://ideas.repec.org/a/jes/journl/y2019v10p151-159.html (accessed on 12 April 2021).

45. Batabyal, A.A.; Nijkamp, P. Interregional Competition for Mobile Creative Capital with and Without Physical Capital Mobility. Int. Reg. Sci. Rev. 2021. [CrossRef]

46. Andreucci, M.B. Progettare Green Infrastructure-Tecnologie, Valori e Strumenti per la Resilienza Urbana; Wolters Kluver Italia: Milan, Italy, 2017; Available online: http:/ / hdl.handle.net/11573/1265073 (accessed on 22 March 2021).

47. Zuziak, Z. An introduction into the new philosophy of urbanism. Urbanity Archit. Files 2020, 48, 181-206. [CrossRef]

48. Malovics, G.; Cretan, R.; Berki, B.M.; Toth, J. Urban Roma, segregation and place attachment in Szeged, Hungary. Royal Geogr. Soc. Area 2019, 51, 72-83. [CrossRef]

49. Dernbach, J.C. Achieving sustainable development: The Centrality and multiple facets of integrated decision making. Indiana J. Glob. Legal Stud. 2003, 10, 247-285. Available online: https://www.repository.law.indiana.edu/ijgls/vol10/iss1/10 (accessed on 22 March 2021). [CrossRef]

50. Turner, J.; Holmes, L.; Hodgson, F.C. Intelligent Urban Development: An Introduction to a Participatory Approach. Urban Stud. 2000, 37, 1723-1734. [CrossRef]

51. Nassar, U. Principles of Green Urbanism: The Absent Value in Cairo, Egypt. Int. J. Soc. Sci. Humanit. 2013, 3, 339-343. [CrossRef]

52. Vesalon, L.; Cretan, R. "Little Vienna" or “European Avant-Garde city"? Branding narratives in a romanian city. J. Urban Reg. Anal. 2019, 11, 19-34. [CrossRef]

53. Stoddart, H.; Schneeberger, K.; Dodds, F.; Shaw, A.; Bottero, M.; Cornforth, J.; White, R. A Pocket Guide to Sustainable Development Governance. Stakeholder Forum. 2011. Available online: https://www.circleofblue.org/wp-content/uploads/20 12/07/PocketGuidetoSDGEdition2webfinal\%E2\%80\%93Stakeholder-Forum.pdf (accessed on 15 December 2020).

54. Commissione Europea, Relazione della Commissione al Parlamento Europeo, al Consiglio, al Comitato Economico e Sociale e al Comitato delle Regioni-Riesame dei Progressi Compiuti NELL'ATTUAZIONE della Strategia dell'UE per le Infrastrutture Verdi, 184 Final. 2019. Available online: ec.europa.eu/transparency/regdoc/rep/1/2019/IT/COM-2019-236-F1-IT-MAIN-PART-1.PDF (accessed on 22 October 2019).

55. Caragliu, A.; del Bo, C.F. Do Smart Cities Invest in Smarter Policies? Learning From the Past, Planning for the Future. Soc. Sci. Comput. Rev. 2015, 34, 657-672. [CrossRef]

56. Grant, J. Theory and Practice in Planning the Suburbs: Challenges to Implementing New Urbanism, Smart Growth, and Sustainability Principles. Plan. Theory Pract. 2009, 10, 11-33. [CrossRef]

57. Cappochin, G. The sense of a research project: Superurbano, EcoDistricts, European Green Capitals/EcoCities. In European Green Capitals_Experiences of Sustainable Urban Regeneration; Cappochin, G., Botti, M., Furlan, G., Lironi, S., Eds.; LetteraVentidue: Siracusa, Italy, 2017; pp. 7-10.

58. Deakin, M. From intelligent to smart cities. In Smart Cities. Governing, Modelling and Analysing the Transition, 1st ed.; Deakin, M., Ed.; Routledge: London, UK, 2013; pp. 15-32. Available online: https://www.taylorfrancis.com/books/edit/10.432 4/9780203076224/smart-cities-mark-deakin?refId=b7692393-30a7-493b-b012-df4b388d4d12 (accessed on 13 April 2021).

59. Warzecha, B. Kohärente Stadt Wolfsburg. Master's Thesis, Brandenburg University of Technology Cottbus-Senftenberg, Cottbus, Germany, 18 September 2019.

60. Wolfsburg Award for Urban Vision_2020. Wolfsburg's Student Concept Competition on the Theme "Wolfsburg: City I Space I History". Available online: https://www.wolfsburg.de/wolfsburgaward (accessed on 15 April 2021).

61. Reichold, O. ... Erleben, wie eine Stadt Entsteht. Städtebau, Architektur und Wohnen in Wolfsburg 1938-1998; Begleitband zur Ausstellung vom 26. Mai bis 28. August 1998 in der Bürgerhalle des Wolfsburger Rathauses; Meyer: Braunschweig, Germany, 1998.

62. Beier, R. Aufbau West-Aufbau Ost. Die Planstädte Wolfsburg und Eisenhüttenstadt in der Nachkriegszeit; Buch zur Ausstellung des Deutschen Historischen Museums vom 16. Mai bis 12. August 1997; Ostfildern-Ruit: Hatje, Germany, 1997. 
63. Schneider, C. Stadtgründungen im Dritten Reich: Wolfsburg und Salzgitter. Ideologie, Ressortpolitik, Repräsentation; Moos: München, Germany, 1979.

64. Statisches Informationssystem Wolfsburg 2018. Available online: http:/ / rs000455.fastrootserver.de/WolfsburgInteraktiv/JSP / main.jsp?mode=Detailansicht\&area=Stadt\&id=A\&detailView=true, (accessed on 17 March 2019).

65. Statistische Berichte Niedersachsen, Landesamt für Statistik Niedersachsen, Bevölkerungsdichte der Kreisfreien Städte und Landkreise-Stand 31.12.2017. Available online: https://www.statistik.niedersachsen.de/startseite/themen/bevolkerung/ themenbereich-bevoelkerung-statistische-berichte-172949.html (accessed on 19 February 2021).

66. Braunschweig in der Statistik. Available online: http://www.braunschweig.de/politik_verwaltung/statistik/jahrbuch.php (accessed on 19 February 2021).

67. Statistisches Jahrbuch 2017, Salzgitter. Available online: https://www.salzgitter.de/rathaus/downloads/jahrbuecher/Jahrbuch_ 2017.pdf (accessed on 19 February 2021). 